\title{
Üç Boyutlu Sanal Ortamlarda Beş Aşamalı Modelin Uygulanması*
}

\section{Implementation of Five Stage Model in Three Dimensional Virtual Environment}

\author{
Barış ÇUKURBAŞI**, Ayşen KARAMETE***
}

\begin{abstract}
Öz: Bu çalışmada, üç boyutlu sanal ortamlardan biri olan Second Life ortamında beş aşamalı modelin uygulanması ve etkililiğinin belirlenmesi amaçlanmıştır. $\mathrm{Bu}$ amaca ulaşmak için; kullanıcılara oryantasyon eğitimi verilmiş, eğitsel amaçlı bir çalışma ortamı hazırlanması sağlanmış, hazırlanan ortamda eğitim-öğretim aktiviteleri yapılarak katılımcıların ortamdaki deneyimleri hakkında görüşleri alınmıştır. Çalışmada nitel araştırma yöntemlerinden durum çalışması benimsenmiştir. Günlük, görüşme ve gözlem araçları kullanılarak toplanan veriler, beş aşamalı modelin aşamalarına göre analiz edilmiştir. Araştırmanın çalışma grubunu 2010-2011 akademik y1lı bahar döneminde Balıkesir Üniversitesi, Necatibey Eğitim Fakültesi, BÖTE Bölümü ikinci sınıf öğrencilerinden araştırma için gerekli koşulları sağlayan ve çalışmaya gönüllü olarak katılan 19 öğrenci oluşturmaktadır. Araştırma kapsamında günlük ve görüşme ile elde edilen veriler içerik analizi ile çözümlenmiştir. İçerik analizinden elde edilen veriler, gözlem verileri ile desteklenmiştir. Katılımcıların ortamı etkin bir şekilde kullanabildiği, ortamı benimsediği, ortamda sosyalleştikleri, etkili ve rahat bir şekilde kendilerini ifade edebildikleri, bilgi paylaşımları ile yapılan çalışmalarla ürünler ortaya koydukları elde edilen sonuçlar arasındadır. Ayrıca, katılımcıların öğrendikleri bilgileri yapılandırdıkları ve ortamdaki faaliyetlerini gerçek yaşantılarıyla ilişkilendirdikleri, dolayısıyla, beş aşamalı modelin tüm basamaklarını başarılı bir şekilde gerçekleştirdikleri sonucuna ulaşılmıştır.
\end{abstract}

Anahtar Kelimeler: Beş aşamalı model, second life, oryantasyon, uzaktan eğitim, üç boyutlu sanal ortam

\begin{abstract}
The main purpose of the current study was to examine the utility and effectiveness of five stage model in one of the three dimensional environments called second life. To help meet the purpose, users received orientation, a work environment has been established, learning activities took place in this environment and the users' views were received. Case study, a qualitative research method, was used in this study through using diary, conducting interviews and making observations, data were analyzed in light of five stage model. The participants were 19 pre-service teachers studying in Balıkesir UniversityNecatibey Faculty of Education's department of computer education and instructional technology in 2010-2011 academic years' spring semester. The participation was voluntary. Diaries were examined through content analysis technique. Data obtained from this technique were supported from data gathered from observations. The findings revealed that the participants found the environment effective, easy to use, and a place that enabled them to socialize and to express themselves confidently. In addition, they constructed their own knowledge, and connected it with real life; therefore, they achieved all of the stages of five stage model.
\end{abstract}

Keywords: Five stage model, second life, orientation, distance learning, three dimensional virtual environment

\section{Giriş}

Teknolojinin hızla geliştiği bu çağda bilgisayar ve internet kullanımı giderek yaygınlaşmakta ve hemen hemen her ortamda bu teknolojiler bulunmakta, kullanılmaktadır. Özellikle de içerisinde bulunduğumuz zaman gereklerine uygun olarak bilgi ve iletişim teknolojileri (BİT) hemen

\footnotetext{
*Bu çalışma Üç Boyutlu Sanal Ortamlarda Beş Aşamalı Modelin Uygulanması başlıklı yüksek lisans tezinden üretilmiştir.

**Arş. Gör. Dr., Bartın Üniversitesi, Eğitim Fakültesi, Bartın-Türkiye, e-posta: bariscukurbasi@gmail.com

***Yrd. Doç. Dr., Balıkesir Üniversitesi, Necatibey Eğitim Fakültesi, Balıkesir-Türkiye, e-posta: karamete@balikesir.edu.tr
} 
hemen her alanda yaygın bir biçimde kullanılmakta ve bazı sektörler için de vazgeçilmez bir faktör olmaktadır (Keskin, 2011). Ayrıca, bu durum bireylerin, BİT'i etkili bir biçimde kullanmalarını da gerekli hale getirmektedir. Türkiye İstatistik Kurumu Başkanlığı'nın (TÜIK) yapmış olduğu çalışmalarda da bireylerin bilgisayar ve interneti her geçen yıl daha da yaygın olarak kullandığı görülmektedir. TÜİK’in 18 Ağustos 2015 tarihinde açıkladığı rapora göre bireylerin bilgisayar kullanım oranları gün geçtikçe artmaktadır ve her geçen gün daha çok birey bilgisayara ulaşmaktadır (Hanehalkı Bilişim Teknolojileri Kullanım Araştırması, 2015). TÜİK verilerine göre, 2007 yllında evinde bilgisayar bulunan birey oranı \%33.4, 2008 y1lında \%38, 2009 yılında \%40.1, 2010 y1lında \%43.2 ve 2011 yılında \%46.4 olmuştur (Hanehalkı Bilişim Teknolojileri Kullanım Araştırmas1, 2011). 2015 yılına gelindiğinde bu oran \%68.5'e, 2016 yılında ise \%88.9'a yükselmiştir (Hanehalkı Bilişim Teknolojileri Kullanım Araştırması, 2015). 2011 Eylül ayında yapılan bir araştırmaya göre, Avrupa'nın internette en çok zaman geçiren ülkesi Türkiye olmakla birlikte; 23.167.000 kullanıcı olduğu görülmüştür (Comscore, 2011). Bu kullanıc1 sayıs1 2015 yılına gelindiğinde 46.282.850'ye yükselmiş̧ir (Internet World Stats, 2015). $\mathrm{Bu}$ oranlarının artması ile birlikte her geçen gün kullanıcılara sunulan teknolojik olanakların gelişmeye başladığ 1 görülmektedir. Bilgi ve iletişim teknolojileri okulda, evde ve işte günlük yaşamın bir parçası haline gelmiştir. Bilgisayar ve internetin yaygınlaşmasıyla birlikte internet (Web) teknolojileri de ortaya çıkmıştır.

\section{İnternet (Web) teknolojileri}

Web teknolojileri ilk ortaya çıktığı zamanlarda içeriğin tamamı kullanıcılara hazır olarak sunulmuştur. Kullanıcılar ise İnternet sayfası üzerinden sunulan içeriğin okuyucusu ya da izleyicisi konumunda yer almaktaydı. Teknolojideki yaşanan gelişmeler neticesinde Web teknolojileri de gelişmiştir. Böylece başlangıçta var olan ve kullanıcılar ile İnternet sayfaları arasında İnternet sayfalarından kullanıcılara doğru bir bilgi akışının olduğu bilgi merkezli ortama Web 1.0 teknolojileri adı verilmiştir (Kuzu, 2014). Ardından, Web 1.0 teknolojilerindeki gibi kullanıcıların sadece bilgiye erişebilen, pasif olarak kullanabilen kullanıcı olmalarının dışında, aktif bir şekilde bilgiye erişen, bilgi üreten ve paylaşan rolüne sahip oldukları Web 2.0 teknolojileri ortaya çıkmıştır (Yükseltürk ve Top, 2013).İnternet, Web 3.0 ve Web 4.0 teknolojileri ile birlikte gelişimini sürdürmeye devam etmektedir. Bu teknolojilerden Web 2.0, günümüzde yaygın olarak kullandığımız internet teknolojileri arasında yer almaktadır (Çekinmez, 2009).

\section{Web 2.0 teknolojileri}

İnternet sitelerinin daha fonksiyonel olmasını ve insanların internet sayfalarını kişiselleştirmesini sağlayan Web 2.0 teknolojilerinin ortaya çıkmasıyla birlikte, internet siteleri ile bireyler arasındaki etkileşim daha da artmıştır. Web 2.0, kullanıcıların katılımının sağlandığı bir ortam ve yap1 oluşturmaya yarayan sistemler ve içerisinde bir çok uygulamayı gerçekleştirmeyi sağlayan araçlar bulunduran teknolojilerdir (Horzum, 2010). Arslan'ın (2007) yaptığı çalışmaya göre, Web 2.0 teknolojileri, kişisel bilgisayar uygulamalarını internet ortamına aktarmaya çalışarak internet akışını farklı bir yöne kaydırmaktadır ve kullanıcıların etkin katılımını amaçlayan yenilikçi ve özgürlükçü bir anlayış olarak kullanılmaktadır. $\mathrm{Bu}$ teknolojilerin temel amacı, katılımcıların teknik aksaklıklarla karşılaşmadan içerik paylaşmalarını, İnternet'in sosyal etkileşim ve işbirliği imkanlarından yararlanılmasını sağlamaktır (Ata, 2011). Web 2.0 teknolojileri ile birlikte bireylerin internet üzerindeki etkileşim olanakları da arttığı görülmüştür. Ayrıca her zaman her yerden erişilmesine olanak veren tablet bilgisayar, akıllı telefon gibi mobil araçların ortaya çıkması bu teknolojilerin önemini daha da arttırmıştır (Şahin, 2013). Mobil araçların ortaya çıkmasıyla birlikte, günlük yaşamda hemen hemen her alanda Web 2.0 teknolojileri kullanıcılarının yaşamlarına dahil olduğu bu teknolojiler üzerinden yapılan paylaşımlarda görülebilmektedir. Günümüzde bir çok Web 2.0 teknolojisi kullanılmaktadır. Etiketleme ve Etiket Bulutları (Flickr vb.), Canlı Yer İmi (RSS), Mashup, Günlükler (Bloglar), Wikiler (Wikipedia), Multimediya Paylaşımı (Youtube, Odeo vb.), Sosyal Ağlar (Facebook, Myspace vb.) Web 2.0 uygulamalarından bazıları 
oluşturmaktadır (Durusoy, 2011). Second Life, Active World, There gibi üç boyutlu sanal ortamlar da Web 2.0 teknolojilerindendir. Bunlardan ülkemizde en yaygın olarak kullanılan Second Life ortamıdır (Tokel ve Cevizci Karataş, 2014).

\section{Bir Web 2.0 Teknolojisi: Second Life (SL)}

Linden Lab. isimli firma tarafindan 1991 yılında SL projesi çalışmalarına başlanmıştır ve başlangıçta projeye Linden World adı verilmiştir (Rymaszewski ve diğerleri, 2007). 2002 Kasım ayına gelindiğinde Second Life olarak beta yayınına girmiş, 2003 Temmuzda ise tam sürüm olarak yayına başlamıştır. Günlük ortalama çevrimiçi olan kullanıcı sayısı da 25,00040,000 kullanıcı civarında olan SL'in kullanıcı sayıları ile ilgili bilgi Tablo 1'de sunulmuştur (Second Life Grid Survey Region Database, 2012; Second Life Grid Survey, 2016).

Tablo 1. SL kullanıcl verileri

\begin{tabular}{ll}
\hline Tarih & Kullanıcı Sayısı \\
\hline 04 Aralık 2009 & $17,456,832$ \\
20 Ekim 2011 & $25,787,700$ \\
07 Haziran 2012 & $29,517,245$ \\
24 Nisan 2016 & $45,806,110$ \\
\hline
\end{tabular}

SL, internet üzerinden çevrimiçi olarak çalışan bir sistemdir. Kullanıcıları SL ortamında oluşturdukları sanal karakterler (Avatar) temsil etmektedir ve kullanıcılar avatarları aracılığıyla ortamla etkileşime girilmektedir (Rymaszewski vd., 2007). Kullanıcılar SL ortamına, www.secondlife.com sitesi üzerinden üye olup, SL kullanıcı arayüzü yazılımını yine aynı site üzerinden bilgisayarlarına indirip-kurup; üyelik bilgilerini girerek dahil olmaktadır. Kullanıcılar, avatarlarının her türlü fiziksel ve bedensel görüntüsüne kendileri karar vermektedir. Kullanıcılar, SL'e ilk kez giriş yaptıklarında Welcome Island isimli SL'in nasıl kullanılacağına yönelik temel bilgilerin bulunduğu ve kullanıcıların bilgilendirildiği alanda doğmaktadırlar (ortama dahil olmaktadırlar).

SL'de kullanıcıların yapabileceği işlemlerin sınırı yoktur; kullanıcılar hayal ettikleri ve istedikleri her şeyi yapabilmektedirler. Hayvan, robot, herhangi bir nesne ya da istedikleri cinsiyette bir avatara sahip olabilmektedirler. Ayrıca, tüm avatarlar uçabilmektedir. Kullanıcılar avatarları ile gruplar kurup orada etkinlikler düzenleyebilmekte, SL'de tasarlanmış olan dünyanın çeşitli yerlerini veya dünyanın farklı bir yerinde açılmış ve SL'de tasarımı yapılmış olan müzeleri ziyaret edebilmektedir. SL'de kullanıcilar isterse alanda bulunan herkesin görebileceği ya da duyabileceği şekilde genel yazarak (Chat/Sohbet) ya da sözlü olarak iletişim kurabilmekte, isterlerse sadece belirli kullanıcı ya da kullanıcıların görebileceği şekilde yazılı (özel sohbet) ya da sözlü iletişim (IM Chat) kurabilmektedirler. Ayrıca kullanıcılar isteğe bağlı olarak iletişimi desteklemek için SL'de bulunan mimik ve beden dili öğelerini (Gestures) kullanabilmektedirler.

SL üzerinde ortamlar üç boyutlu olarak tasarlanmaktadır. Kullanıcılar tarafından, prim adı verilen üç boyutlu (küp, silindir, dikdörtgenler prizması vb.) nesnelerin ortamda biçimlendirilmesi (boyutlandırıp, renklendirip, şekillendirip vb.) ve birleştirilmesi ile yeni nesneler (ev, araba, masa ve ortamdaki avatarların dışındaki her şey) oluşturulabilmektedir. Bu tasarım sürecinde kullanıcı, tasarladığı nesneyi SL'in çeşitli bakış açıları sayesinde her yönden görebilmekte ve belirlediği bakış açısıyla nesneye müdahale edebilmektedir.

Ortamda kullanıcıların yaptıkları her etkileşimde genellikle İngilizce dili kullanılmaktadır. SL'de Türkçe dil desteği sınırlı bir şekilde verilmektedir. Bu durumda da sadece Türkçe bilen kullanıcıların ortamla etkileşime girmesinde sorunlar meydana gelebilmektedir. Çukurbaşı, Baran, Çolak ve Doğusoy'un (2010) yaptı̆̆ çalışmaya göre, Türkiye'deki SL kullanıcıların \%19,6'sı ortamda yabancı dil eğitimi almak istemektedir. Bu oranla ilgili olarak belirtilen kullanıcı görüşünde kullanıcının yabancı dili daha iyi olsa, ortamla daha iyi etkileşime gireceği belirtilmektedir. Yapılan çalışmalarda, arayüz dilinin farklı 
olmasından dolayı sorun olduğu görülmektedir (Çukurbaşı, Bezir ve Karamete, 2011; Dinçer, 2008). SL üzerinden eğitim-öğretim aktiviteleri de gerçekleşmektedir. Dünya genelinde birçok eğitim kurumu ve üniversite SL'de sanal çalışma alanları ya da sanal kampüsler kurmakta ve bu alanlar üzerinden dünyanın çeşitli yerlerinden sisteme katılan öğrencilerle eğitim-öğretim aktiviteleri gerçekleştirmektedir (Texas State Üniversitesi, Nottingham Üniversitesi, Bahçeşehir Eğitim Kampüsü, vs) .

\section{Ĕ̈itim-Öğretim ve SL}

SL, eğitmen ve öğrencilere bağlı olarak, dünyanın herhangi bir yerinde toplanıp, 3 boyutlu ortamda görüşmelerini ve etkileşime girmelerini sağlayan, esnek ve güçlü bir çevrimiçi ortamdır (Nottingham's Web Campus in Second Life, 2009). Bu özelliği ile gerek öğrenme-öğretme faaliyetlerinin eş zamanlı olarak yapıldığı çevrimiçi, gerekse de farklı zamanlarda yapıldığ çevrimdışı uygulamalar geliştirme olanağı bulundurduğu için SL ortamı aynı zamanda uzaktan eğitim ortamı olarak da kullanılabilmektedir. Bir çok üniversite ve eğitim-öğretim kurumu tarafından SL'de adalar/alanlar oluşturulmakta, o üniversitenin ya da kurumun sanal ortama dahil olan öğrencileriyle eğitim-öğretim faaliyetleri gerçekleştirilmektedir. Bu eğitim-öğretim faaliyetleri, öğrencilerin normal hayatta katıldıkları dersleri destekleyici olabilmekle birlikte, yine normal hayatta öğrendikleri teorik bilginin sanal ortamda uygulanmasını sağlayıcı şekilde de olabilmektedir. Ayrıca, derste anlatılacak soyut kavramların SL'de tasarlanarak öğrencileri o alana dahil edip, anlatılacak olan bilgileri daha verimli bir şekilde öğrencilere aktarıldığı alanlar da bulunmaktadır. Örneğin, bir derste coğrafi özellikleri anlatılan bir kasabayı sanal ortamda tasarlayıp, öğrencileri o kasabaya götürerek dersi anlatmak yerine, sanal ortama dahil edip, ortamda o kasabayı gezdirerek anlatım yapılmaktadır. Hatta ortamdaki etkileşimli materyaller sayesinde öğretmen olmadan da öğrenciler istedikleri zaman ortama girip, kasabayı inceleyebilmektedirler (Texas State University - San Marcos, 2008).

SL'de öğrenciler, avatarları vasıtasıyla gerçek yaşam simülasyonları ile oluşturulan çeşitli formlardaki bilgileri yeniden yapılandırarak ve etkileşime girmektedir (Chen, 2016). Bu bağlamda SL'de avatarlar bir alanda toplanarak tartışma grupları oluşturabilmekte ve bir konu hakkında görüş alışverişi yapabilmektedirler. Bununla birlikte herhangi bir konu hakkında sanal seminerler de verilebilmektedir. Fisher'in (2010) yapmış olduğu çalışmaya göre, SL'deki konferansların, gerçek yaşamda gerçekleştirilen video konferanslara göre çok daha iyi olduğu görülmektedir.

Eğitsel açıdan bakıldığında SL, yapılandırıcı öğrenme, sosyalleşme, araştırma, keşfetme ve yaratıcılık için yeterli alanlar sağlamaktadır (Burgess, Slate, Rojas-LeBouef ve LaPrairie, 2010). Bu bağlamda kullanıcılar, SL'de tasarlanan medya paneli (internet tarayıcısı), slayt panosu, akıllı tahta vb. etkileşimli birçok nesneyi ve ayrıca o an gerçekleştirebilecekleri birçok tasarım unsurlarını kullanarak; yapacakları eğitim-öğretim etkinliklerini daha etkili bir hale getirebilmektedirler.

SL'de gerçekleştirilen eğitim-öğretim etkinliklerinde genellikle bir ya da birden fazla öğretim yöntem, teknik ve öğrenme yaklaşımı kullanılmaktadır (Petrakou, 2010; Lowe, 2009; Burgess vd., 2010; Çukurbaş1 vd., 2011). Planlanan ve gerçekleştirilen eğitim öğretim faaliyetlerinin, yapılandırıcı öğrenme yaklaşımını temel alan senkron ya da asenkron uzaktan eğitim faaliyetleri olduğu görülmektedir. Öğretim tekniklerinden rol oynama tekniğini SL ortamında uygulayarak gerçekleştirilen bir çevrimiçi uzaktan eğitim kursunda, öğrencilerin danışmanlık becerilerinin geliştiği görülmüştür (Walker, 2009). Rol oynama tekniğinin kullanıldığı lise öğrencilerine yönelik yapılan başka bir çalışmada da SL'nin öğrencilere gerçeğe yakın bir İngilizce konuşma ortamı oluşturulduğu düşünülmektedir. Ayrıca, öğrencilerin İngilizce konuşmaya yönelik becerilerinin arttığını hissettikleri belirtilmektedir (Bezir, Çukurbaşı ve Baran, 2011a). Altı şapkalı düşünme, beyin firtınası, rol oynama, drama gibi öğretim teknikleri kullanılarak SL üzerinde birçok eğitim-öğretim etkinlikleri yapılmıştır (Bezir ve diğerleri, 2011a; Bulu ve İşler, 2011; Vasileiou ve Paraskeva, 2010). Eğitim-öğretim etkinlikleri gerçekleştirilirken kullanılan yöntem ve tekniklerin yanında, uygulama geliştirme 
modelleri de bulunmaktadır. Five Stage Model (Beş Aşamalı Model - FSM) bu uygulama geliştirme modellerinden birisidir.

\section{Five Stage Model (Beş Aşamalı Model - FSM)}

Beş aşamalı model, Salmon tarafindan 1990'lı y1llarda araştırılıp, tasarlanan, geliştirilen ve çevrimiçi ağ üzerinden (uzaktan eğitim ile) eğitim ve öğretim için test edilmiş bir modeldir (Salmon, Nieve Edirisingha, 2010). Ayrıca, çevrimiçi ve karma öğrenme ortamları için farklı seviyeler ve eğitim düzeyleri üzerinden eğitim uygulama-geliştirme modelidir (Salmon vd., 2010).

Bugünün çevrimiçi öğreticileri, artan çeşitli beklentileri, öğrenme stilleri, bilgisayar ve iletişim becerileri olan öğrencilerle uğraşmaktadırlar ve onların çevrimiçi katılımlarından ve öğrenme topluluklarından etkilenmektedir (Muirhead, 2002). Eğiticiler için en önemli soru, aktif öğrenmeye uygun ve işbirlikli çalışmaktan hoşlanan öğrencilere bu ihtiyaçlarını karşılamak için ne gibi olanaklar sağlanabileceğidir. Bu sorunun yanıtlanmasında beş aşamalı model önem arz etmektedir (Salmon, 2000).

Salmon beş aşamalı model ile ilgili ilk araştırmasını (2000) bilgisayar destekli konferans üzerinden yaptığı için modelin aşamalarını bu araştırma bulguları ile yorumlamıştır. Bu modelde, her bir üst basamağa geçildiğinde öğrencinin öğrenme düzeyi ve ortamla (kişi, nesne vb.) etkileşim miktarı artmaktadır. Beş aşamalı modelin basamakları şu şekildedir:

\section{Aşama - Giriş ve Motivasyon Aşaması}

İlk aşamada öğrencilerin etkili katılım sağlaması için, bazı bireysel ön koşulların (sisteme giriş yapabilmesi ve öğrenmeyi gerçekleştirmek için uzaktaki grupla çalışmalarında faydalı olabilmesi) sağlanması gerekmektedir (Salmon vd., 2010). Buradaki en önemli konu, öğretmenler ve katılımcıların sisteme başarıyla giriş yapmaları ve sistemde vakit geçirerek motive olmalarıdır (Salmon, 2004a).

\section{Aşama - Çevrimiçi Sosyalleşme}

İkinci aşama, bireysel olarak çevrimiçi kimlik oluşturmayı ve etkileşime girecek diğer kişileri bulmayı içermektedir (Salmon vd., 2010). Katılımcılar için çevrimiçi etkileşimler ayarlanmalıdır. Birçok katılımcı sistemi, yeni ve muhtemel yabancı bir dünya olarak görecektir. Bundan dolayı katılımcılar birbirlerini tanımalı ve birbirlerinin farkında olmalıdırlar. Ayrıca, sistemde çevrimiçi olma duygusu geliştirilmelidir. Bunun dışında, katılımcılar çevrimiçi davranışlar ile ilgili rehberliğe ihtiyaç duyacaktır. Katılımcıların bu ihtiyaçlarının karşılanması gerekmektedir (Salmon, 2004a). Bu aşamada, yukarıdaki ihtiyaçları karşılama görevi olan eğitimcinin en temel rolü, katılımcılar arasında köprüler kurmaktır (Salmon, 2004b).

\section{Aşama - Bilgi Alışverişi}

Üçüncü aşamada katılımcılar sistemin ve çalışmanın akışı ile ilgili kullanışlı ve uygun bilgi alışverişi yapmalı, çalışmalarla ilgili görevler almalıdır. İlk üç aşamada, her bir katılımcının kendi amaçlarına uyacak şekilde bireysel olarak desteklenmesi sağlanmalıdır (Salmon vd., 2010).

Katılımcılar, çok çeşitli bilgilerin olduğunu, bu bilgilerin nasıl kolay ve hızlı bir şekilde değiştiğini anlamaya başlar. Her ne kadar katılımcılar, bilgi miktarından endişelenseler de potansiyellerini arttıracak stratejileri geliştirmeleri gerekmektedir. Çok rahat ve serbest bir bilgi akışı vardır. Gerekli bilgiyi yanıtlama yükü ise çok azdır. Bu aşamadaki etkileşim, bilginin miktarıyla veya paylaşılmasıyla meydana gelmektedir (Salmon, 2004a).

\section{Aşama - Bilginin Yapılandırılmast}

Dördüncü aşamada, katılımcılar birbirleriyle katılımcı bir yolla etkileşime girmeye başlarlar (Salmon, 2000). Bu aşamada katılımcılara, karmaşık ve yapılandırıcı görevler verilebilir, tartışma yapılabilir ve işbirlikli etkileşimler başlayabilir (Salmon vd., 2010). Öğrenciler birbirlerine (çoğu aktif öğrenme içerikli) mesajlarla yanıt vermektedirler. Bu aşamada eğitmen, 
çok önemli bir rol oynamaktadır. Sistemdeki becerisi en iyi olan eğitmen, grup yapısı ve bakımı ile ilişkili olarak katılımcılara becerilerini gösterir (Salmon, 2004a).

\section{Aşama - Geliş̧tirme}

Beşinci aşamada, katılımcılar sistemden nasıl daha çok faydalanacaklarını araştırırlar. Kendi hedeflerine ulaşma konusunda yardım almak ve çevrimiçi tecrübelerini diğer öğrenme biçimleriyle nasıl birleştireceklerini keşfetmek isterler. Ayrıca, kendi öğrenmelerini gerçek hayata transfer edip uygularlar. Yani, bireysel öğrenme, öğrenilen bilginin transferi ve yansımasıyla meydana gelmektedir (Salmon vd., 2010).

Beş aşamalı model, öğrenciler ve eğitmenleri arasında nitelikli ve yoğun bir etkileşimle, olumlu bir süreci (ilerlemeyi) yansıtmaktadır. Çevrimiçi öğreticilerin rolü, öğrencilerin bireysel ihtiyaçlarını karşılayarak öğrenmelerini sağlamaktır (Salmon, 2000).

\section{Beş aşamalı modelin sanal ortamlarda uygulanışı: $S L$}

Diğer sanal ortamlardan farklı olarak SL, bir üç boyutlu sosyal uygulama yazılımıdır ve kullanıcilar hayal ettikleri ve istedikleri her şeyi ortamda yapabilmektedirler. Salmon ve diğerleri (2010) yaptığı çalışmada, beş aşamalı modeli SL ortamında uygulayarak bu modelin basamakları SL'e uygun olacak şekilde düzenlemiştir. Beş aşamalı modelin SL'e uyarlanmış hali Şekil 1'de görülmektedir.

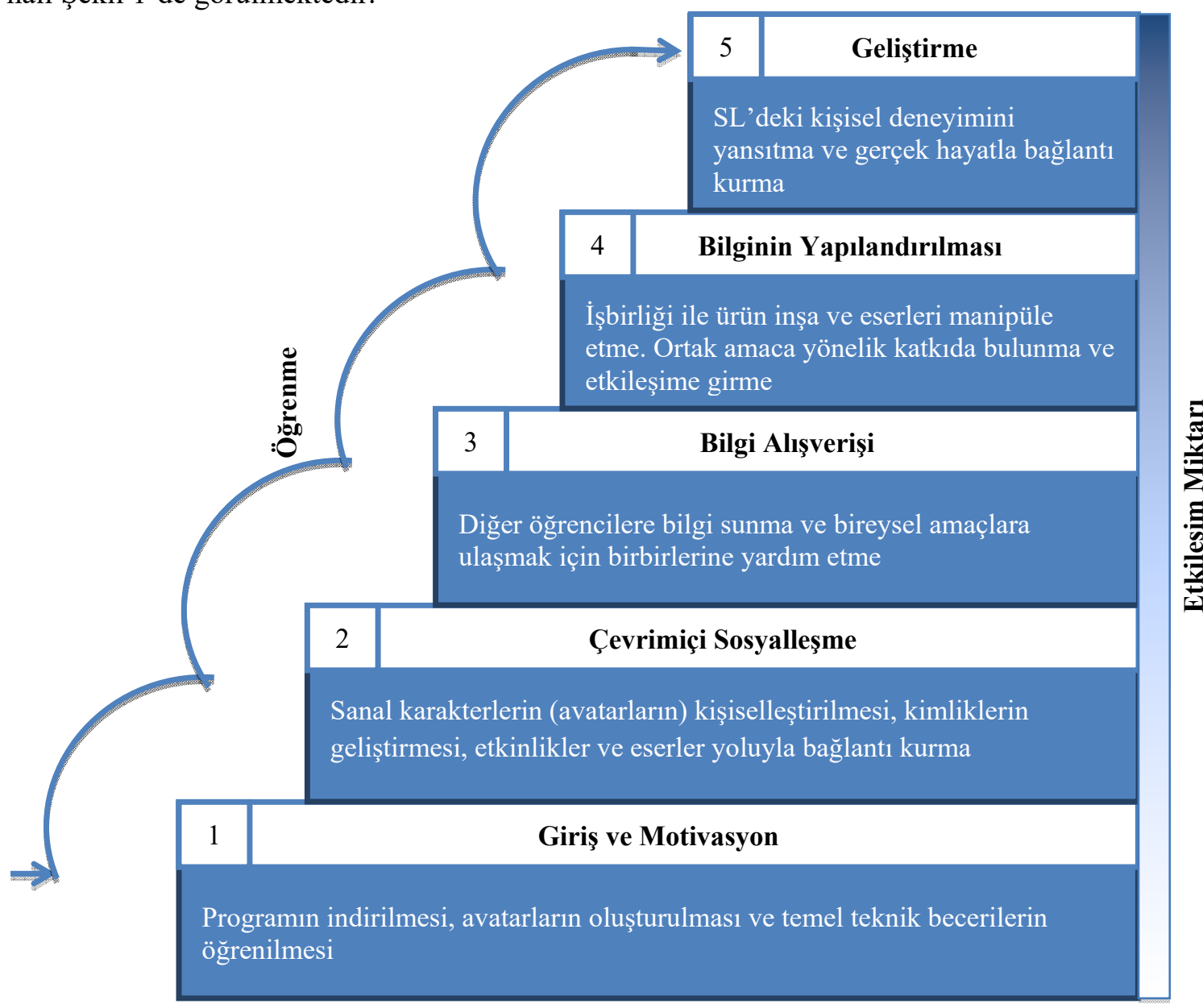

Şekil 1.Beş Aşamalı Modelin SL'e Uyarlanmış Hali (Salmon, Nie ve Edirisingha, 2010)

Salmon ve diğerleri (2010) çalışmalarında, modelin SL'deki kullanışlılığını ve uygunluğunu test edip raporlaştırmışlardır. Çalışmada, eğitmenler ve öğrenciler için sanal bir ortam ve aktiviteler, beş aşamalı model temel alınarak tasarlanmıştır. Veriler, yarı yapılandırılmış görüşmeler ve ortamdaki yazışma kayıtları ile toplanmış ve analiz edilmiştir. 
Çalışmanın sonucu olarak, modelin her aşamasının SL'de bir öğrenme firsatı sunduğu görülmüştür. Salmon'un gerçekleştirdiği ilk çalışmayla karşılaştırıldığında, beş aşamalı model kullanılarak gerçekleştirilen SL uygulamalarının, en az asenkron metin tabanlı ortamlar kadar iyi sonuçlar verdiği görülmüştür.

Yapılan incelemelerde SL ve beş aşamalı model ile ilgili olarak öğrenme öğretme süreçlerinde kullanılması ile ilgili olarak yurtdışında gerçekleştirilen çalışmalar olduğu görülmektedir. Ancak ülkemizde bu teknoloji ve modelin bir arada kullanıldığı bir çalışmaya rastlanılmamıştır. Dolayısıyla ülkemizde $\mathrm{SL}$ ve beş aşamalı model kullanılarak gerçekleştirilecek bir öğrenme faaliyetlerinin gerçekleştirilmesinin etkilerinin neler olacağ merak edilmektedir. Gerek SL gibi web 2.0 teknolojileri, gerekse beş aşamalı model gibi uygulama geliştirme modelleri gibi öğrencileri öğrenme sürecinin merkezine getiren ortamların öğrenme öğretme süreçlerindeki olumlu yönde etkileri, öğrenci merkezli yaklaşımları, sanal ortamlar üzerinde gerçek yaşam deneyimleri kazanmaları ve çevrimiçi sosyalleşerek öğrenmelerini sağlamaları gibi etkileri göz önüne alındığında bu teknoloji ve modelin kullanılabilme durumlarının derinlemesine incelenmesini ve bu konuda bir çalışma yapılmasını gerekli hale getirmiştir.

\section{Araştırmanın önemi}

SL'de, SL'nin kullanımına yönelik birçok Oryantasyon Alanı bulunmasına rağmen, bu alanlara yönelik yapılmış Türkçe bir bilimsel çalışmaya rastlanılamamıştır. Ayrıca, sadece Türkçe bilen kullanıcıların ihtiyacını karşılayacak bir Oryantasyon Alanına rastlanılamamıştır. Bu yönüyle araştırmanın alana katkı sağlayacağı ve sadece Türkçe bilen kullanıcılara yönelik tasarlanıp test edilmiş Oryantasyon Alanının, SL ortamında gerçekleştirilmesi planlanan bilimsel çalışmalara katkı sağlayacağına inanılmaktadır.

Beş aşamalı modelin SL'e uyarlanmış hali 2010 yılında geliştirilmiştir. Bu sebepten ötürü, yapılan araştırmanın beş aşamalı modelin temel alınarak gerçekleştirilmesinin ve uygulanmasının modelin öğrenme öğretme sürecinde kullanılmasına yönelik katkılar sağlayacağına, modelin ülkemizde kullanılması hususunda Türkçe bir kaynak niteliğinde olacağına inanılmaktadır.

\section{Araştırmanın amacı}

Araştırmada, üç boyutlu sanal ortamlardan biri olan SL ortamında beş aşamalı model temel alınarak katılımcılara SL'nin kullanımına yönelik oryantasyon eğitimi verilmesi, eğitsel amaçlı bir çalışma ortamı hazırlanmasının sağlanması, hazırlanan ortamda eğitim-öğretim etkinlikleri yapılarak katılımcıların ortamdaki deneyimleri hakkında görüşlerinin alınması ve uygulanan beş aşamalı modelin etkililiğinin belirlenmesi amaçlanmıştır.

\section{Araştırmanın sınırlılıkları}

$\mathrm{Bu}$ araştırma Balıkesir Üniversitesi Necatibey Eğitim Fakültesi Bilgisayar ve Öğretim Teknolojileri Eğitimi Bölümünde 2010-2011 Eğitim Öğretim Bahar Yarıyılı ile 2011-2012 Güz Yarıyılında ikinci ve üçüncü sınıfta öğrenim gören 19 gönüllü öğrenci,İşletim Sistemleri dersinin bir haftasının SL ortamında işlenmesi ve SL ortamında iki sanal konferansın düzenlenmesi ile sınırlıdır.

\section{Yöntem}

Araştırma modeli olarak nitel araştırma yöntemlerinden durum çalışması kullanılmıştır. Araştırmanın yaklaşımını belirleyen ve çeşitli aşamalarının bu yaklaşımla ilişkili olmasında yol gösterici bir strateji olan nitel araştırma yöntemleri, gözlem, görüşme ve döküman incelemesi gibi nitel veri toplama yöntemlerinin kullanıldığı, algıların ve olayların doğal ortamda gerçekçi ve bütüncül bir biçimde ortaya konmasına yönelik nitel bir sürecin izlendiği araştırmalardır (Yıldırım ve Şimşek, 2008). 


\section{Çalışma grubu}

Araştırmanın çalışma grubunun belirlenmesinde amaçlı örnekleme yöntemlerinden ölçüt örneklemesi kullanılmıştır. 2010-2011 akademik yılı bahar döneminde Balıkesir Üniversitesi Necatibey Eğitim Fakültesi Bilgisayar ve Öğretim Teknolojileri Eğitimi Bölümü’nde birinci öğretim ve ikinci öğretim olarak ikinci sınıfta öğrenim görmekte olan, çalışmaya gönüllü olarak katılan ve SL'ye bağlanabilmesi için gerekli olan ölçütleri sağlayan öğrenciler çalışma grubunu oluşturmuş̧tur. Bu ölçütler aşağıda sıralanmıştır:

- SL için minimum donanım özelliklerine sahip bir bilgisayara istendiğinde ulaşılabilecek olmalı,

- Kesintisiz ve hızlı bir internet bağlantı hızına sahip olmalı,

- İstediği zaman SL'e bağlanabilmeli,

- Sesli iletişim kurmak için mikrofon, hoparlör gibi çevre birimlerine sahip olmalı.

Öğrencilere gerekli bilgilendirmeler yapıldıktan sonra çalışmaya katılmayı gönüllü olarak isteyen ve gerekli ölçütleri sağlayan 35 öğrenci ile araştırmaya başlanmıştır. Ancak, düzenli olarak çalışmaya katılmayan, teknik (donanımsal ve internet hızı kaynaklı) sorunlar yaşayan veya veri toplama araçlarını düzenli ve etkili olarak doldurmayan öğrencilere ait veriler araştırmaya dâhil edilmemiştir. Böylece BÖTE Bölümü ikinci sınıfında öğrenim gören 19 öğrenci ile araştırmanın verileri oluşturulmuştur. Çalışma grubu 13 kadın, 6 erkek öğrenciden oluşmuştur. Bu öğrencilerin 19-24 yaş aralığında yer almış ve öğrencilerin yaş ortalaması 20,8 olarak hesaplanmıştır.

Çalışma sanal ortam üzerinden, öğrencilerin ders saatleri dışındaki bir zamanda gerçekleştirildiğinden dolayı birinci öğretim ve ikinci öğretim öğrencileri ile birlikte eşzamanlı olarak çalışılmıştır.

\section{Araştırmacının çalışmadaki rolleri}

Araştırmacı, çalışma grubunu belirleme aşamasında kendisini tanıtıp, çalışmanın yapılacağ 1 SL ile ilgili genel bir bilgilendirme yapmıştır. Ardından kendisinin ortamda neler yaptığını, neler kazandığını, kendisini nasıl geliştirmekte olduğunu anlatmıştır. Daha sonra, yapmayı planlandığ çalışma ile ilgili bilgiler vermiş ve bu çalışmaya katılmak isteyen öğrencilerin katılabileceğini; ancak bu çalışmanın tamamen gönüllülük esasına ve belirli ölçütlerin sağlanmasına bağlı olduğunu belirtmiştir. Bu doğrultuda katılımcılar belirlenmiştir.

Araştırmacı, uygulamalar esnasında SL ortamında katılımcılara beş aşamalı modelin de gerektirdiği gibi danışman olarak görev yapmıştır. Çalışmanın başlangıcında tüm katılımcılar SL'e yabancı oldukları için ortamın oryantasyonu sırasında araştırmacı hem eğitici hem de danışman rolünde görev yapmıştır. Uygulamanın diğer bölümlerinde sürekli olarak danışman olarak görev yapmıştır. Ancak çalışma başlangıçlarında (toplanma sürecinde), ara verildiğinde, çalışma tamamlandığında veya çalışma saatleri dışındaki zamanlarda katılımcılarla araştırmacı bir araya geldiklerinde onlardan biri gibi, katılımcılarla genel olarak sohbet etmiş, bilgi alışverişi yapmış, derslerle ve çalışmalarla ilgili görüş alıverişi yapmıştır. Bu yolla veri toplama sürecinde katılımcılardan daha sağlıklı ve güvenilir veri elde edilmesi amaçlanmıştır.

Araştırmacı, veri toplama sürecinde araştırmacı rolüne geçiş yapmış ve bu doğrultuda veri toplama işlemini gerçekleştirmiştir. Ayrıca, araştırmacı farklı iki rolde gözlem yapmıştır. İlki, uygulama sırasında katılımcılara danışmanlık esnasındaki gözlem verileridir. İkincisi ise yapılan uygulamaların kaydedilen ekran kayıtlarının incelemesi esnasında oluşan gözlem verileridir. Görüşme verileri toplanırken araştırmacı tamamen araştırmacı rolüne geçiş yapmıştır ve daha yararlı verileri elde edebilmek için çalışmıştır.

Uygulamalar boyunca, SL ortamına, araştırmacı tarafindan üç farklı bilgisayardan, üç farklı sanal karakterle giriş yapılmıştır. SL'deki çalışma alanının geniş olmasından dolayı, alanın değişik alanlarındaki katılımcılarla hızlı bir şekilde ilgilenebilmek için bu yöntem tercih edilmiştir. Bütün sanal karakterlerle ekran kaydı yapılmıştır. Ayrıca, üçüncü sanal karakterin bakış açısı çalışma alanının tümünü genel olarak görecek şekilde ayarlanıp, özel durumların haricinde sadece ekran kaydı yapmak için kullanılmıştır. Çalışmada araştırmacının bir temel sanal karakteri (Barocraft Tremor) ve dört yardımcı sanal karakteri bulunmuştur. Bu 
karakterlerden temel sanal karakter, her uygulamada aktif olarak bulunmuş, diğer karakterlerden de herhangi ikisi uygulama sırasında aktif olarak bulunmuştur.

\section{Araştırmanın uygulama ve veri toplama süreci}

Araştırma, 2010-2011 akademik yılı bahar dönemi ve 2011-2012 akademik yılı güz dönemi olmak üzere iki dönemde gerçekleştirilmiştir. Uygulamanın 2010-2011 akademik y1lı bahar dönemindeki kısmı altı hafta, 2011-2012 güz dönemindeki kısmı ise beş hafta sürmüştür. Çalışma zamanları katılımcıların vize ve final sınavları zamanlarına denk gelmeyecek şekilde düzenlenmiş, böylece öğrencilerin daha aktif olarak çalışmalara katılabilmesi için ortam hazırlanmıştır.

Beş aşamalı model temel alınarak, 2010-2011 akademik yılı bahar döneminde SL'nin kullanımına yönelik oryantasyon eğitimi verilmiş; 2011-2012 akademik yılı güz döneminde ise SL'de katılımcılarla birlikte bir çalışma ortamı tasarlanmıştır. Tasarlanan sanal ortamda, uzaktan eğitimle ders işlenerek çalışma tamamlanmıştır.

Örneklem seçimi için öğrencilere yapılan bilgilendirme sunumu ile birlikte araştırma sürecince sadece ilk iki hafta öğrencilerle yüz yüze olarak laboratuvar ortamında çalışma gerçekleştirilmiş olup, diğer tüm uygulamalar tamamen SL üzerinden gerçekleştirilmiştir.

Araştırmacı ve katılımcılar bulundukları yerden SL'ye bağlanıp çalışmaları gerçekleştirmişlerdir.

Araştırma sürecinde katılımcıları bilgilendirmek, uygulama zamanları dışında iletişimi sağlamak ve uzaktan veri toplamak için araştırmacı tarafından bir internet sitesi hazırlanmış (secondlife.cevrimiciogreniyorum.com) ve öğrencilerin sisteme üye olmaları sağlanmıştır. Böylece öğrenciler, site üzerinden bilgileri takip etmiş ve gerekli işlemleri yapmışlardır.

Çalışma grubunun çalışmaya eksiksiz katılmalarını sağlamak için katılımcılarla beraber çalışma zamanları belirlenmiştir. Bir çalışma için iki bazen üç farklı zamanda karar kılınıp, hangi zaman diliminde gelmeye uygunsa katılımcı, o zaman çalışmaya katılmıştır. İsteyen katılımcı her üç zaman diliminde de çalışmaya katılmıştır. Uygulama saatleri dışındaki zamanların büyük bir kısmında araştırmacı ortamda aktif olarak bulunmuş ve gelen katılımcılarla ilgilenmiş ve isteyen katılımcılara danışmanlık yapmıştır. Ayrıca, çalışma zamanları ve iletilmesi gereken bilgiler, uygulama saatleri dışında öğrencilere kısa mesaj (SMS), e-posta gönderimi ile ve secondlife.cevrimiciogreniyorum.com internet sitesi üzerinden duyuru olarak iletilmiştir.

\section{Oryantasyon Alant}

Uygulamanın ilk altı haftalık kısmında katılımcılara SL ortamının kullanımına yönelik oryantasyon çalışması yapılmış, bu doğrultuda oryantasyon eğitimi için beş aşamalı model temel alınarak uygulama gerçekleştirilmiştir. Oryantasyon Alanının tasarımı ve geliştirilmesi sırasında erişime açık olan SL kullanımına yönelik oryantasyon alanları incelenmiş, eksikliklerolması gerekenler not alınmıştır. Yapılan literatür çalışması sonucunda SL'in kullanımına yönelik hazırlanmış oryantasyon alanlarıyla ilgili bir bilimsel çalışmaya rastlanılamamıştır. Bundan dolayı SL ortamı üzerinde gerçekleştirilen inceleme doğrultusunda oryantasyon alanları tasarlanmıștır.

Yapılan çalışmaların ardından, beş aşamalı model göz önünde bulundurularak çalışma alanının taslağı oluşturulmuştur. Çalışma alanının Oryantasyon Alanı bölümü 3 parçaya ayrılmıştır: SL'in temel kullanımını içeren bilgilerden oluşan Oryantasyon Alanı 1, SL'de tasarım yapmanın dişındaki bilgilerin tamamından oluşan ve bu bölüme ek olarak kıyafet (nesne etkileşimi) ve soyunma kabinlerinin de bulunduğu Oryantasyon Alan1 2 ve üçüncü olarak da SL'de tasarım yapmanın anlatıldığı tasarım oryantasyonu alanı. Uygulama alanında, oryantasyon alanlarının dışında, bir oditoryum, bir konferans alanı, üç grup çalışması alanı ve iki serbest vakit geçirme alanı oluşturulmuştur. Tasarlanan alanlar için önce ihtiyaç duyulacak alan hesaplanarak çalışma alanı için SL'de $1 / 4$ ada (Quarter Sim, $~ 15,000 \mathrm{~m} 2$ ) alan kiralanmıştır. Çalışma alanının tasarlanan krokisi Şekil 2'de verilmiştir. 


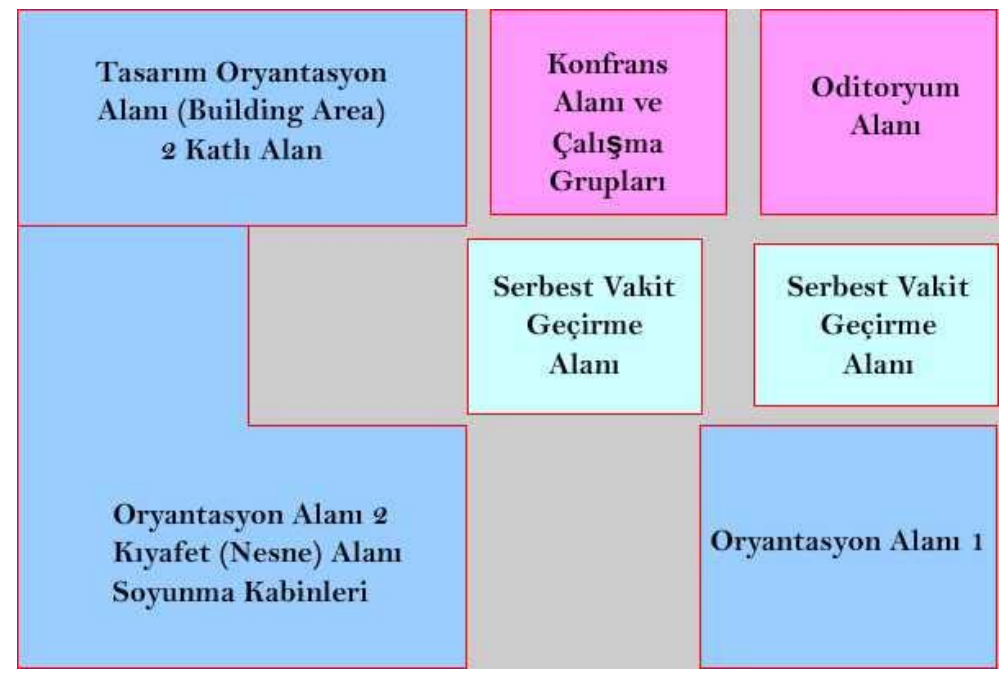

Şekil 2.Çalışma Alanının Krokisi

SL'nin kullanımını katılımcıların küçük parçalar halinde aşama aşama öğrenmeleri için bu alanlar kademe kademe aktif hale getirilmiştir. Yani, uygulamanın ilk haftası sadece Oryantasyon Alanı 1 aktif olarak görüntülenmiştir. Bir sonraki hafta Oryantasyon Alanı1 ile birlikte Oryantasyon Alanı2 aktif edilmiştir. Bu şekilde oryantasyon eğitimi aşama aşama gerçekleştirilmiştir.

\section{Hafta: araștırma örnekleminin belirlenmesi}

Araştırmanın çalışma grubunu oluşturacak katılımcılar belirlenmiştir.

\section{Hafta: SL ortamına üyelik ve ilk giriş}

$\mathrm{Bu}$ çalışma laboratuar ortamında yüz yüze olacak şekilde gerçekleştirilmiştir. Birinci öğretim ve ikinci öğretim öğrencileri ile iki ayrı oturumda çalışma yapılmıştır. Katılımcılara SL ile ilgili daha ayrıntılı bilgiler verilmiştir. Ardından SL'e üye olmaları, SL arayüz yazılımını indirip kurmaları ve sisteme girmeleri konusunda araştırmacı tarafından danışmanlık yapılmıştır.

Giriş yapıldıktan sonra katılımcılara, SL'deki çalışma alanına nasıl gidecekleri (Teleport-1şınlanma) konusunda danışmanlık yapılımıştır. Çalışma alanına gelen katılımcılara SL oryantasyonuna başlamadan önce, öğrenmeleri gereken öncelikli bilgiler (yazılı iletişim kurma, yürüme, nesnelere bakma vb.) verilmiştir.

\section{Hafta: SL Oryantasyon Alanı 1}

Katılımcılarla uzaktan bağlantı yoluyla ilk sanal ortam buluşması bu hafta Oryantasyon Alanı 1'de gerçekleştirilmiştir. Katılımcılar bu alandaki panolardaki yazılı ve görsel anlatımları inceleyip, uygulayarak SL'nin kullanımına yönelik temel becerileri öğrenmişlerdir. Çalışma sırasında sorun yaşayan katılımcı olduğunda araştırmacı danışman olarak gerekli olan yardımı gerçekleştirmiştir. Katılımcıların ek nesne gerektiren (oturmak için koltuk gereksinimi gibi) anlatımları uygulaması için, Oryantasyon Alanı 1'de ilgili nesneler hazır bulundurulmuş ve katılımcıların denemesine sunulmuştur. Oryantasyon Alanı 1 çalışması tamamlandıktan sonra, çalışmayı tamamlayan katılımcılardan secondlife.cevrimiciogreniyorum.com sitesine üye girişi yaptıktan sonra erişilebilen "Günlük 1" ismiyle hazırlanmış olan alana o haftaki çalışmalarla ilgili günlük yazmaları istenmiştir.

\section{Hafta: SL Oryantasyon Alanı 2}

Oryantasyon Alanı 2 çalışmasında da katılımcılar hazırlanan panolar yardımıyla ortamla (nesnelerle, kıyafetlerle vb.) nasıl etkileşime girecekleri ve sanal karakterlerinin hem fiziksel hem de dış görüntüsünü nasıl düzenleyebilecekleri anlatılmıştır. Çalışmalar sırasında katılımcıların ortamla etkileşime girebilmesini sağlayan nesneler Oryantasyon Alanı 2 içerisinde 
hazır olarak bulundurulmuştur. Çalıșma tamamlandıktan sonra yine internet sitesi üzerinden katılımcıların giriş yapmaları ve bu uygulama sonrası için hazırlanmış olan "Günlük 2" alanına uygulama ile edindikleri tecrübelerini yazmaları istenmiştir.

\section{Hafta: SL tasarım oryantasyonu 1. çalışma}

Oryantasyon eğitiminin üçüncü aşaması olan tasarım öğretimi (Building) için iki hafta ayrılmıştır. Tasarım çalışmasının ilk haftası genellikle tasarım Oryantasyon Alanının zemin katında gerçekleşmiştir. Burada, panolardaki içerikleri inceleyip, uygulayan katılımcılar bir üst kata çıkarak, isterse orada maket olarak bulunan nesnelerden (ev, masa, sandalye vb.) birini, isterse zihninde canlandırdığı herhangi bir nesnenin tasarımını yaparak öğrendiği bilgiyi pratiğe dökmektedir. Oryantasyon Alanı aşama aşama etkinleştirildiği için sonraki hafta yapılacak uygulama için kullanılacak tasarım Oryantasyon Alanının ikinci katı etkinleştirilmemiştir. Onun yerine katılımcılara farklı bir çalışma alanı sunulmuştur. Herhangi bir sorun yaşandığında gerekli danışmanlık hizmeti araştırmacı tarafından verilerek çalışma gerçekleştirilmiştir.

\section{Hafta: SL tasarım oryantasyonu 2. çalışma}

SL kullanımına yönelik olarak verilen oryantasyon eğitiminin son haftasında, katılımcılarla tasarım oryantasyonuna devam edilmiştir. Araştırmacı, öğretici kimliği ile panolardaki çalışmaları destekleyici şekilde, gösterip yaptırma tekniğini kullanarak tasarım yapılmasıyla ilgili eğitim vermiştir. Eğitim, tasarım Oryantasyon Alanının bu hafta etkinleştirilen ikinci katında gerçekleştirilmiştir. $\mathrm{Bu}$ alanda bulunan panolarda katılımcılara bir önceki haftada üzerinde çalıştıkları bilgileri hatırlatıcı kısa açıklamalar bulunmaktadır. Çalışma tamamlandığında, katılımcılardan tasarım oryantasyonu için iki haftalık tecrübelerini yansıtacak “Günlük 3”ü yazmaları istenmiştir.

\section{1-2012 güz dönemi uygulamast}

Araştırmanın ikinci bölümünde yani 2011-2012 güz döneminde, katılımcılarla birlikte bir SL çalışma ortamı tasarlanmış ve bu ortamda eğitim-öğretim aktiviteleri gerçekleştirilmiştir. Araştırmacı tarafından bahar dönemi için hazırlanan çalışma alanı tamamen kaldırılmış ve ortamda sadece bir serbest vakit geçirme alanı bırakılmıştır. Dönemin ilk toplantısı o alanda gerçekleştirilmiş ve öğrencilere yeni çalışma ile ilgili bilgiler verilmiştir.

İlk toplantıda katılımcılara bu alanda eğitim-öğretim aktiviteleri gerçekleştirmek için bir ortam tasarımı yapılacağı ve tasarımının sonunda da örnek uygulama ya da uygulamalar yapılacağı aktarılmıştır. Ardından bir sonraki buluşmaya kadar katılımcılardan bir araya gelerek, nasıl bir ortam tasarımı yapılabileceği konusunda beyin firtınası yapmaları ve tartıştıkları fikirleri listelemeleri istenmiştir. Beyin fırtınası için katılımcıların rastgele iki gruba ayrılmaları istenmiş ve grupların homojen (birinci öğretim ve ikinci öğretim karışık) olarak dağılımını sağlamak için araştırmacı tarafindan öğretim türünün heterojen olduğu rastgele iki grup oluşturulmuştur. Her grup içinde rastgele olarak birer sorumlu seçilmiştir. Sorumluların görevi, grupların bir araya gelip çalışmasını organize etmek ve çalışma gününde yaptıkları çalışmayı ve hazırladıkları taslakları tüm katılımcılara aktarmak olarak belirlenmiştir.

Çalışmanın bir sonraki toplantısında yani ikinci hafta, araştırmacı tarafından katılımcıların yaptıkları çalışmaları daha iyi tartışabilmek için, doğal ortam içerisinde sanal sınıf tasarlanmıştır. Ardından, iki gruba ayrılan katılımcılardan alınan taslak çizimler SL ortamına aktarılıp sanal sınıfta gösterilmiştir.

İki gruba ayrılmış olan katılımcılar ve danışman rolündeki araştırmacı sanal sınıfta bir araya gelmişlerdir ve ortamdaki üç boyutlu sanal ekranda gruplardan birinin yaptıkları taslak çizimlerden bir parçası görüntülenmiştir. Grup sorumluları, grup üyelerinin de destekleriyle/katkılarıyla yaptıkları çalışmaların taslak çizimlerini diğer katılımcılara ve danışmana anlatmışlardır. Her anlatım sonrası yine beyin fırtınası yapılarak daha iyi bir tasarımın nasıl yapılabileceği konusunda fikir üretilmiştir. Böylece yapılacak ortam tasarımı için temel şablon oluşturulmuştur. Oluş̧urulan temel şablon Şekil 3'te verilmiştir. 


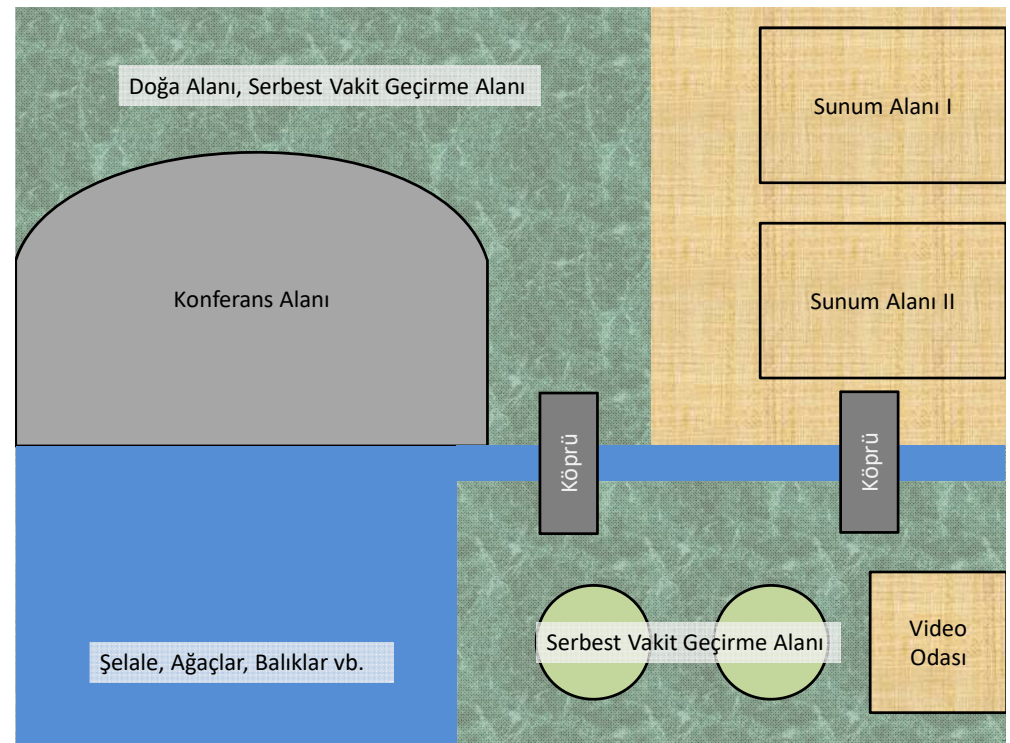

Şekil 3.Katılımcılarla Birlikte Geliştirilen Sanal Ortam Taslă̆

Şekil 3'te sunulan şablon hazırlandıktan sonra katılımcılarla birlikte iş bölümü yapılmıştır. İş bölümü yapılırken katılımcıların istekleri göz önünde bulundurulmuştur. Birkaç katılımcı ortamdaki serbest vakit geçirme alanları için kendi tasarımlarını yapmak istemişlerdir. Diğer katılımcılardan bazıları çevre düzenlemesini (ağaçlar vs.) yapmak, bazıları köprüleri yapmak, bazıları da konferans alanını tasarlamak istemişlerdir. Araştırmacı bu doğrultuda danışmanlık rolü gereği her gruba tasarım konusunda katkıda bulunacağını belirtmiştir.

Üçüncü haftada araştırmacı ile birlikte katılımcılar, ortam tasarımına devam etmişlerdir. Dördüncü haftaki uygulama öncesinde, araştırmacı tarafından uygulama süresini uzatmamak için, katılımcılarla birlikte tasarlanan nesnelere bazı müdahalelerde bulunulmuştur. Nesnelerin bir bütün olarak görünmesi, kayan noktaların düzeltilmesi, hizalanması, renklendirilmesi, görüntü yüklenmesi ve yerleştirilmesi hususunda küçük müdahaleler yapılmıştır. Dördüncü hafta uygulaması başladığında da katılımcılara bu konuda gerekli bilgilendirmeler yapılmış ve müdahale edilen nesneler katılımcılarla birlikte teker teker incelenmiştir. Katılımcıların önerileri doğrultusunda gerekli düzenlemeler yapılmış ve çalışma alanına son hali verilmiştir.

Dördüncü hafta çalışmasıyla birlikte SL sanal çalışma ortamı tasarlanmıştır. Çalışmanın son haftadaki uygulamasında, katılımcıların normal hayatta sınıf ortamında işledikleri dersin uygulama haftasına denk gelen konusu SL ortamında işlenmiştir. Katılımcıların öğretim programları ve ders programları göz önüne alınarak bu gerçek hayat uygulamasının İşletim Sistemleri dersinde olmasına karar verilmiştir. Bu bağlamda çalışma grubunda yer almayan öğrenciler dersi sınıf ortamında normal bir şekilde işlemişlerdir. Çalışma grubundaki öğrenciler ise sınıf ortamındaki derse katılmamış, aynı ders haftasının farklı bir gün ve saatinde SL'ye bağlanıp, dersi öğretim üyesinin de ortama katılmasıyla sanal ortamda işlemişlerdir. Dersin öğretim üyesine, çalışma öncesi dersi anlatabilmesi için gerekli olan SL kullanımıyla ilgili bilgilendirmeler yapılmıştır. Ders öncesinde, öğretim üyesi tarafından ortamda ders anlatımı sırasında kullanmak üzere videolar hazırlanmıştır. Videolar anlatılacak içeriğin görüntülerinden oluşmakta ve ses içermemektedir. Yani, ortama resimler koymak yerine, anlatılacak bilgi ile ilgili sürecin daha iyi görüntülenebilmesi için videolar hazırlanmıştır. Bu videolar, çalışma alanındaki konferans salonunda bulunan medya paneliyle öğrencilere sunulmuştur.

Sanal ortamda işlenen ders 80 dakika sürmüştür. Dersin sonunda, katılımcılar ve öğretim üyesi tarafindan tekrar ders işleme isteği sunulmuştur ve öğretim üyesi bir sonraki hafta da dersi SL üzerinden işlemeyi katılımcılara teklif etmiştir. Fakat tatil dönemine girileceğinden dolayı katılımcılar, bulunacakları ortamlarda bilgisayar ya da internet erişimi sıkıntıları yaşayacaklarını söylemişlerdir. $\mathrm{Bu}$ nedenle, çalışma bu etkinlikle sonlandırılmıştır. Araştırmanın uygulama süreci tamamlandıktan sonra, katılımcılarla SL ortamı üzerinden 
görüşme yapılarak veriler toplanmıştır. Bu bağlamda 19 katılımcı ile SL üzerinden görüşülmüştür.

\section{Veri toplama araçları}

Durum çalışmasının doğası gereği incelenen durumun detaylı bir şekilde ortaya konması gerekmektedir. Bundan dolayı, durum çalışmalarında birden fazla veri toplama aracı kullanılması, araştırmaya daha geniş bir açıdan bakma olanağı sağlar (Yıldırım ve Şimşek, 2008). Ayrıca, araştırmada incelenmek istenen özelliklerin türüne göre, uygun olacak veri toplama araçları seçilmelidir. Crocker'ın (2011) nitel araştırmalarda kullanılan veri toplama araçlarının incelenecek durumları inceleme boyutları incelenmiş ve araştırma kapsamında kullanılan veri toplama araçları belirlenmiştir. $\mathrm{Bu}$ bağlamda araştırmada sanal karakterlerin ortamdaki davranışlarını incelemek için en iyi veri toplama araçlarından biri olan gözlem tekniği kullanılmıştır. SL ortamında öğrencilerin sanal karakterleri ile sergiledikleri davranışlar, SL'in iletişim-etkileşim özellikleri ile yaptıkları görüşmeler ve çalışmalara katılma durumları araştırmacı tarafından gözlenmiştir. Aynı zaman araştırmacı oluşturduğu ek sanal karakterler ile farklı iki bilgisayardan daha SL ortamına bağlanarak, farklı noktalara yerleştirmiş ve ekran kaydı vasıtasıyla SL ortamındaki çalı̧̧ma alanının tamamının çalışma sırasında kayıt altına alınması sağlanmıştır. Her çalışma tamamlandıktan sonra araştırmacı tarafından gözlem notları alınmıştır. Bunun yanında diğer iki bilgisayar tarafından yapılan ekran kayıtları ve öğrencilerin iletişim-etkileşim faaliyetleri incelenmiştir. Alınan gözlem notları bu incelemeler doğrultusunda yeniden düzenlenmiş ve gözlem verilerini oluşturmuştur.

Katılımcıların düşüncelerini ve duygularını incelemek için de en iyi veri toplama araçlarından ikisi olan günlük ve yarı yapılandırılmış görüşme kullanılmıştır. Günlük araştırmada SL oryantasyon alanı çalışması (birinci aşama) sırasında kullanılmıştır. Öğrencilerden her çalışma sonunda hazırlanan internet sitesi üzerindeki ilgili bölüme girerek günlük tutmaları istenmiştir. Çalışmanın ikinci aşamanın sonunda öğrenciler ile ayrı ayrı yarıyapılandırılmış görüşme yapılmıştır. Yarı-yapılandırılmış görüşme formu yedi maddeden oluşmuştur. Her maddenin altında öğrencilerden derinlemesine bilgi almayı sağlamaya yönelik olarak 'sonda' ifadeler yer almıştır. Yarı-yapılandırılmış görüşme formu hazırlanması aşamasında literatür taraması yapılarak taslak form oluşturulmuş, uzman görüşü alınarak form hazırlanmıştır. Ardından gerçekleştirilen çalışma ve araştırmacı deneyimlerine bağlı olarak form yeniden düzenlenmiş ve tekrar uzman görüşü alınarak forma son hali verilmiştir. Yarıyapılandırılmış görüşme formunda "Normal hayatta arkadaşlarınızla kurduğunuz iletişim ile sanal dünyadaki kurduğunuz iletişim arasındaki farklılıkları ve benzerlikleri açıklar mısınız?" ve "Sanal ortam oluşturmak için diğer katılımcılarla yaptığınız çalışmalar hakkında neler düşünüyorsunuz?" gibi maddeler ve bu maddelerin altında katılımcıların verdikleri yanıtlara göre katılımcılara yönlendirilen "sonda" ifadeler yer almıştır.

Günlük uygulamanın birinci aşamasında, görüşme ise uygulamanın ikinci aşamasında kullanılmıştır. Gözlem ise uygulama boyunca sürekli olarak yapılmıştır.

\section{Araştırmanın geçerlik ve güvenirliği}

Araştırmacı, hem uygulama zamanlarında hem de uygulama dışındaki zamanlarda katılımcılarla sürekli olarak etkileşim sağlamıştır. Bu etkileşimin sağladığı yakınlıkla, görüşme ve günlükler doldurulurken katılımcılar daha rahat ve samimi cevaplar vermişlerdir. Ayrıca, katılımcıların duygu, düşünce ve davranışlarını daha iyi belirlemek için görüşme, günlük ve gözlem olmak üzere üç farklı veri toplama aracı kullanılmıştır.

Çalışmanın ilk uygulaması bölümünde araştırmacı tarafından oluşturulan sanal ortam tasarımı hazırlanırken, veri toplama araçları geliştirilirken ve gerek duyulan her aşamada uzman görüşlerine başvurulmuş ve gerekli düzenlemeler yapılmıştır. Görüşme ile veri toplanırken katılımcılara hiçbir şekilde yönlendirici sorular sorulmamış, tarafsız bir şekilde en güvenilir veri toplanmaya çalışılmıştır. Veri toplama araçları ile elde edilen sonuçlar birbirleriyle karşılaştırılmıştır ve varsa birbirleriyle olan ilişkileri ortaya çıkartılmaya çalışılmıştır. Ayrıca, çalışmada hem birinci öğretim hem de ikinci öğretim öğrencileriyle çalışılmıştır ve bu 
öğrencilerin genellikle farklı yapılara sahip oldukları görülmüştür. Araştırmanın aktarılabilirlik boyutunun sağlanması bağlamında, amaçlı örnekleme yöntemlerinden ölçüt örneklemesi kullanılmıştır. Ayrıca, yapılacak benzer çalışmalar için, araştırma sonuçlarının genellenebilmesi bakımından, araştırma süreci detaylı bir şekilde açıklanmıştır. Elde edilen veriler tarafsız bir şekilde hiç yorum katılmadan incelenmiştir. Ayrıca araştırmacı, katılımcı ifadelerinden alıntılar yapmıştır. Yapılan ortam tasarımları da görsellerle desteklenerek betimlenmiştir.

Araştırmanın tutarlılığı için katılımcılarla görüşmeler yapılırken, sorular her zaman aynı sırada sorulmuştur. Hiçbir şekilde katılımcıyı yönlendirici ifadeler kullanılmamıştır. Ayrıca, elde edilen bulguların alıntılarla desteklenmesine ve araştırmanın amaciyla olan tutarlılığına dikkat edilmiştir. Elde edilen verilerin analizi aşamasında yapılan tüm işlemler kayıt altına alınmış ve tekrar tekrar denetlenmiştir. Ayrıca, Eğitim Teknolojileri Anabilim Dalında ve Eğitim Programları ve Öğretim Anabilim Dalında yüksek lisans yapan iki akademisyen tarafından da elde edilen görüşme ve günlük verileri analiz edilmiştir. Analiz sonuçları birbirleriyle karşılaştırılarak son haline getirilmiştir.

\section{Verilerin analizi}

Araştırmada elde edilen verileri analiz etmek için içerik analizi yapılmıştır. Bu bağlamda, görüşme ve günlük yoluyla toplanan veriler derinlemesine incelenerek kodlanmış; bu kodlar arasındaki ilişkiler incelenerek temalar ortaya konmuş ve temalar arasındaki ilişkiler açıklanmaya çalışılmıştır. Analiz sonucunda elde edilen veriler, gözlem sonuçlarıyla desteklenerek daha anlamlı sonuçlar ortaya konmaya çalışılmıştır.

Araştırmanın amacı doğrultusunda beş aşamalı modelin aşamalarına göre verilerin analizi yapılmış ve bulgular gruplandırılmıştır. Bu doğrultu da Tablo 3'te verilen tablodaki doğrultusunda veri analizi yapılmış ve bulgular gruplandırılmıştır.

Tablo 3. Bulgular Oluşturulurken Oluşturulan Gruplar ve Özellikleri

\begin{tabular}{|c|c|c|}
\hline \multicolumn{2}{|c|}{ Bulgu Bölümleri } & İncelenecek Durumlar \\
\hline 1. Aşama: & $\begin{array}{l}\text { Giriş ve } \\
\text { Motivasyon }\end{array}$ & $\begin{array}{l}\text { Katılımcılara ortam hakkında bilgilendirmenin yapılması. } \\
\text { Katılımcıların üye olup, SL yazılımını indirip-kurup, sisteme giriş yapmaları. } \\
\text { Çalışma alanına gidilmesi ve doğru yerde beklenilmesi. } \\
\text { Ortam ile ilgili temel ve teknik becerilerin öğretilmesi }\end{array}$ \\
\hline 2. Aşama: & $\begin{array}{l}\text { Çevrimiçi } \\
\text { Sosyalleşme }\end{array}$ & $\begin{array}{l}\text { Sanal karakterlerin hem fiziksel hem de dış görünüş olarak biçimlendirilmesi/ } \\
\text { kişiselleştirilmesi. } \\
\text { Sanal kimliklerin oluşturulması. Ortamdaki etkinlikler ve eserleri yoluyla } \\
\text { gerçek yaşamla bağlantı kurma. Sanal ortamı benimseme. }\end{array}$ \\
\hline 3. Aşama: & Bilgi Alışverişi & $\begin{array}{l}\text { Katılımcıların ortak amaca ulaşmaya yönelik bilgi alışverişi yapmaları, } \\
\text { önerilerde bulunmaları ve diğer katılımcılara yardımcı olmaları. }\end{array}$ \\
\hline 4. Aşama: & $\begin{array}{l}\text { Bilginin } \\
\text { Yapılandırılması }\end{array}$ & $\begin{array}{l}\text { Uygulama süresince katılımcıların yaptıkları işbirliğgi ve paylaşımlar. } \\
\text { Bu işbirliği ve paylaşımlar çerçevesinde ortamda ürünler ortaya konulması ya da } \\
\text { var olan eserlerin manipüle edilmesi. } \\
\text { Ortak olarak ürün ortaya koyma aşamasında da tüm katılımcıların birlikte } \\
\text { çalışması. }\end{array}$ \\
\hline 5. Aşama: & Geliştirme & $\begin{array}{l}\text { Uygulama süreci tamamlandıktan sonraki durum. } \\
\text { Katılımcıların uygulama süreci sonunda yansıttıkları tecrübeler. }\end{array}$ \\
\hline
\end{tabular}

\section{Bulgular}

Araştırmanın amacı gereği verilerden en iyi bulguları elde edebilmek için, katılımcıların hem davranışlarını (sisteme giriş yapabilmesi, sanal karakteri kullanabilmesi gibi), hem düşüncelerini (bilgiyi yapılandırması, gerçek hayatla bağlantı kurması gibi) hem de duygularını (motivasyonları, ortamdaki hisleri gibi) incelemek gerekmektedir (Crocker, 2011). Bu bağlamda, araştırma verilerinin kodlanması sürecinin başında ana tema gruplar (düşünce, duygu ve davranış) belirlenmiş ve elde edilen kodlar bu tema gruplarından uygun olanlarına yerleştirilmiştir. Ardından yerleştirilen kodlara göre temalar ve alt temalar oluşturulmuştur. Tüm uygulama süreci boyunca araştırmacı sürekli olarak sistemde aktif olarak bulunmuş, katılımcılara uygulamaya göre danışmanlık ve eğitmenlik yapmıştır. 
Düşünce ve duygu tema gruplarına ait veriler günlük ve görüşme yoluyla toplanan verilerin analizinden elde edilmiş ve tablolaştırılmıştır. Davranış tema grubuna ait veriler ise gözlem verilerinin analizi ile elde edilmiş açıklanarak yorumlanmıştır.

Bulgular oluşturulurken katılımeı ifadelerine yer verilmiş̧ir. $\mathrm{Bu}$ ifadelerin hangi katılımcı ve hangi veri toplama aracı ile elde edildiği kodlama ile verilmiştir. Bu kodların yanına günlük 1 için $G 1$, günlük 2 için $G 2$, günlük 3 için $G 3$ ve Görüşme için $M$ kodlar1 eklenmiştir.

\section{Giriş ve motivasyon aşamasına ilişskin bulgular}

Birinci aşamaya ilişkin katılımcılardan toplanan üç günlükten elde edilen veriler Tablo 4'te sunulmuştur.

Tablo 4. Giriş ve Motivasyon Aşamasına İlişkin Temalar

\begin{tabular}{|c|c|c|c|c|c|}
\hline \multicolumn{6}{|c|}{ Düşünce } \\
\hline \multicolumn{2}{|c|}{ Oryantasyon Alanları } & \multicolumn{2}{|c|}{ Second Life } & \multicolumn{2}{|r|}{ Danışman } \\
\hline $\begin{array}{l}\text { - Yeterli } \\
\text { - Ayrıntılı } \\
\text { - Açık } \\
\text { - Anlaş1lır } \\
\text { - Kullanışlı } \\
\text { - Gayet iyi } \\
\text { - Tekrar etme olanağ1 } \\
\text { - Güzel bir ortam } \\
\text { - Öğretici } \\
\text { - Etkileşimli } \\
\text { - Oyun oynar gibi }\end{array}$ & \multicolumn{2}{|c|}{$\begin{array}{l}\text { - Kullanım kolaylığı } \\
\text { - Kurulum kolaylığı } \\
\text { - Gerçek hayata yakınlık } \\
\text { - İletişim olanağı } \\
\text { - Jest ve mimikler gerçekçi } \\
\text { - Avatarla etkin katılım olanağ } \\
\text { - İkinci bir yaşam } \\
\text { - Dil gelişimi } \\
\text { - Üç boyutlu düşünme olanağı } \\
\text { - Grafik ve yazılım gelişimi }\end{array}$} & $\begin{array}{l}\text { - Dil sorunu } \\
\text { • Teknik } \\
\text { sorun } \\
\text { • Kullanımı } \\
\text { detaylı }\end{array}$ & \multicolumn{2}{|c|}{$\begin{array}{l}\text { - Yardım alma } \\
\text { - İyi iletişim sağlama } \\
\text { - Kolay öğrenme } \\
\text { - Bilgi tamamlayıcı } \\
\text { - Eğitici } \\
\text { - Yeterli yönlendirme }\end{array}$} \\
\hline \multicolumn{6}{|c|}{ Duygu } \\
\hline \multirow{2}{*}{ Motivasyon } & \multicolumn{2}{|c|}{ Second Life } & \multicolumn{3}{|c|}{ Çalışmalar } \\
\hline & Olumlu & Olumsuz & Olumlu & & Olumsuz \\
\hline $\begin{array}{l}\text { - Oyun gibi } \\
\text { - Merak } \\
\text { - Etkinlikler } \\
\text { heyecanlı } \\
\text { - İlgimi çekiyor } \\
\text { - Hoşlanma } \\
\text { - Kişisel gelişim } \\
\text { - Eğlenceli } \\
\text { - Firsat } \\
\text { - Kullandıkça } \\
\text { motivasyonum } \\
\text { artıyor } \\
\text { - Avatar kullanımı }\end{array}$ & $\begin{array}{l}\text { - Eğlenceli } \\
\text { - İşlem çokluğu } \\
\text { - Rahatım } \\
\text { - Uçmak çok } \\
\text { zevkli } \\
\text { - Kullanmaktan } \\
\text { zevk alıyorum } \\
\text { - Sikılmama } \\
\text { - Işılnlanmak çok } \\
\text { güzel bir his } \\
\text { - Sinıf stresi } \\
\text { olmuyor } \\
\text { - Çok sevdim }\end{array}$ & $\begin{array}{l}\text { - Başlangıçta } \\
\text { çekindim } \\
\text { - Uçmak } \\
\text { saçma }\end{array}$ & $\begin{array}{l}\text { - Başarılıyım } \\
\text { - Öğrenmek güzel } \\
\text { - Avatar ile daha ilgi } \\
\text { - İlerledikçe merakım } \\
\text { artıyor } \\
\text { - Paylaşmak güzel } \\
\text { - İlerledikçe daha faz } \\
\text { sevmeye başladım } \\
\text { - Kendime güveniyor } \\
\text { - önyargilarımdan } \\
\text { kurtuldum } \\
\text { - Çalışma duygusunu } \\
\text { motive eden bir ortan } \\
\text { - Ortam motivasyonu } \\
\text { artırıyor } \\
\text { - Danışmanın özel } \\
\text { ilgilenmesi mutlu edi }\end{array}$ & & $\begin{array}{l}\text { - Başlangıçta } \\
\text { yanlış bir şey } \\
\text { yapmakta } \\
\text { korktum } \\
\text { - Başlangıçta } \\
\text { tedirgindim } \\
\text { - Başlangıçta } \\
\text { gerçekçi ve ilgi } \\
\text { çekici gelmedi }\end{array}$ \\
\hline
\end{tabular}

Tablo 4'te görüldüğü gibi katılımcılardan elde edilen verilerin 1şığında, giriş ve motivasyon aşamasıyla ilgili olarak üç ana tema grubu altında temalar, alt temalar ve kodlamalar oluşturulmuştur.

Düşünce tema grubuna ait bulgular incelendiğinde, katılımcıların tamamının oryantasyon alanları ile ilgili olarak olumlu ifadeler kullandıkları, büyük bir çoğunluğunun oryantasyon alanlarını çok iyi, anlaşılır ve yeterli düzeyde bulduğu, panolarda bulunan anlatımların açık ve öğretici olduğu ifade edilmiştir. Ayrıca, SL'ye yönelik olarak da katılımcıların yarısına yakını tarafından arayüz dilinin Türkçe olmamasından kaynaklı olumsuz bulgulara rastlanmıștır. İletişim olanağı, elde edilen bulgular arasında önemli bir yere sahiptir. 
Katılımcılar, çalışmaların yapıldı̆̆ 1 ve dersin işlendiği zamanlarda gerektiğinde kimseyi rahatsız etmeden birbirleriyle ve danışmanla özel iletişim yollarını kurarak iletişime geçtiklerini ifade etmişlerdir.

Duygu teması ile ilgili olarak, katılımcılardan bazılarının çalışmanın başlangıcında çekingenlik ve tedirginlik yaşadığ çalışma haftaları ilerledikçe bu duygularından kurtulduklarını ifade etmiş̧lerdir. Bununla birlikte, katılımcıların büyük bir çoğunluğunun başlangıçta motivasyonlarının yüksek olduğu ve ortama giriş yaptıktan sonra ortamdaki birçok şeyin nasıl gerçekleştiğini merak ettikleri elde edilen önemli bulgular arasındadır. Çalışma süresince katılımcıların motivasyonlarının, SL'ye yönelik olumlu düşüncelerinin ve ortamdaki rahatlıklarının giderek arttığı bulgularına ulaşılmıştır.

Davranış tema grubu ile ilgili olarak, katılımcıların büyük bir kısmı öğrenip de yapamadığı bir işlemin olmadığını; diğer kısmı ise çalışmalar ilerledikçe daha iyi sanal karakterlerini kullandıklarını ifade etmişlerdir. Sadece iki katılımcıdan başlangıçta sanal karakteri uçarken kontrol sorunu yaşadığı ve yine iki katılımcıdan da avatarın kullanımının zor olduğu bulgularına ulaşılmıştır.

Uygulama sürecinde gerek ekran kayıtlarının gerekse araştırmacının danışman olarak yaptığ1 gözlem verilerine yönelik bulgular şu şekildedir:

Çalışmanın yüz yüze laboratuvar ortamında geçen ilk iki haftalık uygulamasında yapılan gözlemlerde, katılımcıların ilk kez böyle bir sanal ortamın varlığından haberdar oldukları görülmüss, ortamdaki yapılabilecekleri ve bireysel olarak sağlayacağı kazançlar aktarıldığı sırada ise genel olarak çalışma isteğinin oluştuğu, motivasyonlarının arttığ gözlenmiştir. Laboratuvar ortamındaki ikinci buluşmada katılımcılar, SL'ye ilk kez üye olup, arayüz yazılımını indirip-kurup, sisteme giriş yapmışlardır. Bu işlemler süresinde araştırmacı danışman olarak görev yapmış ve tüm katılımcılarla ayrı ayrı ilgilenmiştir. Bu işlemlerde sorun yaşayan katılımcıya rastlanılmamıştır.

Katılımcilar ortama ilk kez girdiklerinde laboratuvarda genel bir heyecan ve mutluluk havası oluşmuştur. Ancak bazı katılımcıların da sistemde yanlış bir şey yapmamak için çok dikkatli olmaya çalıştığı gözlenmiştir. Daha sonra katılımcılar çalışma alanına ışınlanmışlardır. Çalışma alanında araştırmacı tarafından katılımcılara, bir sonraki hafta çalışılacak olan Oryantasyon Alanı 1'deki çalışmaları yapabilmeleri için gerekli olan temel ve teknik bilgilendirmeler yapılmışır. Bu haftanın sonuna gelindiğinde herhangi bir sorun yaşayan katılımc1 gözlenmemiştir.

Oryantasyon Alanı 1'den itibaren, tüm çalışma sanal ortam üzerinden gerçekleşmiştir. Bundan dolayı araştırmacı tarafından ortamdaki sanal karakterler ve diğer sanal karakterlerle kurdukları iletişimler gözlenmiştir. Bu gözlemler 1şığında oryantasyon alanlarını çalışan katılımcıların pek sorun yaşamadığı görülmüştür. Meydana gelen sorunlar ya da katılımcılar tarafından yöneltilen sorular danışman tarafindan hemen ilgilenilerek çözülmüştür. Ayrıca çalışmalar sürecinde araştırmacı, danışmana karşı olabilecek bir çekingenliği aşma, veri toplama sürecinde daha sağlıklı veriler toplamak adına samimi bir hava oluşturma ve katılımcıların eksiksiz çalışmaları tamamlamasını sağlamak için her katılımcı ile ayrı ayrı iletişime geçmiştir.

Giriş ve motivasyon aşaması kapsamında elde edilen bulgulara ilişkin katılımcı ifadelerinden bazıları şunlardır:

-Second Life çok hoşuma gitti. Farklı bir dünya gibi galiba gerçekten de ikinci yaşamım olacak $\therefore$.). Seçtiğim avatarım da hoşuma gitti sanki benmişim gibi kendime göre onu yönlendirmek, daha pek yapamasam da onu giydirmek çok eğlenceli. Bunun yanında işin içinde eğitim olmasl en güzeli, bir şeyler katacaksa bana mekan fark etmez gerçek veya sanal:). Kısacasl güzel şeyler olacak gibi hissediyorum ve buna bağlı olarak da iyi düşünüyorum. P16G1

-Ortamdayken işlemleri çok rahatllkla yapabiliyorum. Bu rahatllğım biraz da olsa önceden oyun oynamamdan kaynaklaniyor sanırım. Fakat hiç oyun oynamamış olsaydım da yine rahatllkla işlemler yapabileceğime inaniyorum. Çünkü bu ortamda hiçbir şey zor değil. Çok iyi tasarlanmış. Ortamda kendimi rahat hissediyorum. Avatarımı rahatlikla kontrol edebiliyorum. P5G1 
-... Özellikle çok fazla etkileşim sunması açısından ve basit bir kurulumdan sonra sadece bir üyelik ile bu dünyaya katılma sunmass bulunmaz bir nimetti. Avatarımla ilerleme ve dış görünüşünü değiştirmenin yanı sıra 3 boyutlu tasarımlara imkan sağlaması gibi büyük zenginliklerinin olması beni buna daha fazla yönlendirdi. $\mathrm{P} 1 \mathrm{M}$

-İlk başladı̆̆ımda ortamı kavramaya çalıştım. Nasıl bir mantık yürütmüşler ne kullanmışlar diye düşünüyordum ki oryantasyon bölümünde ayrıntılarlyla buldum bunlarl. Oryantasyonda ilk seviye olan avatarl hareket ettirmekten en zor kismı yani bence en zor kismı olan buildinge kadar bilgi vardı ve bana 10 dakikada bütün sistemi neredeyse çözme imkanı verdi. $\mathrm{P} 4 \mathrm{M}$

-Tanıtıldı̆̆ında kaçırılmayacak bir firsat olduğunu düşündüm... Ayrıca sanal ortamda ĕgitim görecek olmak heyecan vericiydi. Second Life'ta avatarımı kontrol edebilmek Second Life'ı kullanmaya yönelik motivasyonumu arttırdı. Aynı zamanda Second Life gibi üç boyutlu programları kullanmaya teşvik etti. Bir avatar ile sanal ortamda eğitim görmek hoşuma gitti. P6M

\section{Çevrimiçi sosyalleşme aşamasına ilişkin bulgular}

İkinci aşamaya ilişkin katılımcılardan toplanan üç günlükten ve yapılan görüşmelerden elde edilen veriler Tablo 5'te sunulmuştur.

Tablo 5.Çevrimiçi Sosyalleşme Aşamasına İlişkin Temalar

Düşünce

Öneri

- Sözel derslerin
işlenmesi
- Uygulamalı ders
işlenmesi
- Uzaktan eğitim
verilebilir

- Sözel derslerin

verilebilir
Gerçekçilik

Olumlu

Olumsuz

Genel
- Yüz yüze olmaması • Sosyal bir ortam

- Kiyafet sorunu • Ortam insanı rahatlatiyor

- Beni sosyal

yaşamdan soyutlar samimi

- Ortam tasarımı

- Yüz yüze iletişime

Duygu

\begin{tabular}{|c|c|c|c|c|c|}
\hline Hoşlanma & Heyecan & Motivasyon & Olumsuz & Merak & İlgi çekici \\
\hline $\begin{array}{l}\text { - İletişim } \\
\text { kurmak } \\
\text { - Uçmak çok } \\
\text { hoş } \\
\text { - Ortamları } \\
\text { incelemek }\end{array}$ & $\begin{array}{l}\text { - Seyahat } \\
\text { etmek } \\
\text { - Eğitim } \\
\text { almak }\end{array}$ & $\begin{array}{l}\text { - Sanal } \\
\text { karakter } \\
\text { kontrolü } \\
\text { - Sanal } \\
\text { karakter seçimi }\end{array}$ & $\begin{array}{l}\text { - Yanlış bir şey } \\
\text { yapmaya } \\
\text { korkuyorum }\end{array}$ & $\begin{array}{l}\text { - Sanal } \\
\text { karakterimle } \\
\text { yapllabilecekler } \\
\text { - Diğer sanal } \\
\text { karakterin } \\
\text { görüntüsü }\end{array}$ & $\begin{array}{l}\text { - Sanal karakter } \\
\text { biçimlendirmesi } \\
\text { - Kendi karakteri } \\
\text { olmasi }\end{array}$ \\
\hline
\end{tabular}

Oryantasyon çalışmasının Oryantasyon Alanı 2 bölümünde katılımcılar, sanal karakterlerini nasıl biçimlendireceklerini öğrenir öğrenmez sanal karakterlerini biçimlendirmişlerdir. Katılımcıların büyük bir çoğunluğu, üye oldukları sırada seçtikleri sanal karakterlerini hem fiziksel hem de diş görünüş olarak biçimlendirmiş ve oluşturduğu sanal karakteri ya kendisine en çok benzeyecek hale getirmiş ya da hayal ettiği bir karaktere dönüştürmüştür. Bundan dolayı ortamda etkileşimde bulunduğu karakteri kendisi olarak sahiplenmiştir. Yani sanal kimliklerini oluşturmuşlardır. Ayrıca, katılımcıların çoğunluğu ortamda kendilerini rahat hissettiklerini, sınıfta olsalar bu kadar rahat olamayacaklarını belirtmişlerdir.

Katılımcıların tamamı, ortamdaki eğitim-öğretim olanaklarından memnun olmuşlardır. Ortamdaki iletişim olanaklarından hoşnut olduklarını belirten katılımcılardan bu olanakları gerçeğe çok yakın bulanların sayısının çok olmasına rağmen, dört katılımcı yüz yüze iletişim kurmanın daha iyi olduğunu belirtmiştir. Katılımcıların ortamda yaptıkları çalışmalardan genel olarak hoşlandıkları, eğitim almak ve (özellikle uçarak) seyahat etmekten de heyecan duydukları elde edilen bulgular arasındadır.

Katılımcıların çevrimiçi sosyalleşme aşaması kapsamındaki ifadelerinden bazıları şunlardır: 
-...Ben en çok karakterimin görünümüyle ilgili şeyleri merak ediyorum ve ortamda bununla epey uğraştım. Çözemediğim yerler oldu, onları çözmeyi istiyorum. Ayrıca insanların birbiriyle nasıl etkileşim kurduklarını merak ediyorum... P13G1

-...Kim avatarını nasıl giydirmiş? Ben nasılım diye gerçek hayatta ki gibi düşünür oldum ... ben burada yazarken avatarımın el hareketi, veya hocanın konuşurken yanına yaklaştığımda sesini daha iyi duyabilmem vs. Bunlar gerçek sınıf ortamında yaşanan hadiseler olduğundan ortamın ciddiyetini ve bă̆glılı̆̆ arttırdiğgina inanıyorum. P14G2

-Her şey çok güzel bence ve de yolunda gidiyor, arkadaşlıklar da öyle sanki dışardan daha samimi hoşça vakit geçiriyoruz ... P9G3

-Değişik bir ortam sizi avatarlarınız temsil etmesi ve hareketlerinizi onlarla yansitmak. Bir nevi sorumluluk sanırım... Örneğin fiziksel bir problemi olan bir kişi kendi evinden de rahatlıkla ortama katılarak sorunsuz bir şekilde öğretimi tamamlayabilir. Avatar sayesinde kendini ortamın bir parçası gibi görebilir. Bu yönüyle artı să̆ladı̆̆ını düşünüyorum. P11G2

-... Örneğin dans edilecek yerler ilginç geliyordu, çünkü Second life ortamında her şey gerçekçi ve ilgi çekici hazırlanmış. Lunaparka gitmek de çok hoşuma gidiyordu. Gittiğim yerlerden birinde Ingiliz bir kadın ile tanıştım. Avatarı son derece güzel giyimli ve biçimlendirilmişti. Bana nerelerden bedava klyafet alabileceğimi ve Second Life'da neler yapabileceğimi, dış görünüşümde ne gibi değişiklikler yapabileceğimi anlattı... P13M

-Second life ortamına katılmaya başladıktan sonra bu arkadaşlarımla ortamda sık sık iletişim kurmaya başladım. Bu durum birinci ögretimler içinde geçerliydi. Hiç tanımadı̆̆ım insanlarla Second Life da bir şekilde tanışma firsatı buldum ve yeni arkadaşlıklar edindim... Insanların etkileşimine katkı să̆ladiğ için de Second Life ' a sadece ders için girmiyorum. Zaman zaman farklı ortamlara gidip diğer avatarların tasarladı̆̆ ortamlara bakıp insanlarla muhabbet ediyorum. Bu gerçekten çok ilgi çekici ve güzel bir hal allyor. P16M

-Second Life'ta arkadaşlı̆̆ın artısı, örneğin: bu program olmasaydl benim Texas'dan arkadaşım olamazdı. Second life uygulamalarına katılmaya başladığım günlerde internetten yaptığım araştırmalar ve sizin anlattı̆̆ınız yerlerden ilgimi çok ilgimi çekenlere gittim. Bora Bora Plajında tanıştı̆̆ım biri oldu... P18M

\section{Bilgi alışverişi aşamasına ilişkin bulgular}

Üçüncü aşamaya ilişkin katılımcılardan toplanan üç günlükten ve yapılan görüşmelerden elde edilen veriler Tablo 6'daverilmiştir.

Tablo6.Bilgi Alışverişi Aşamasına İlişkin Temalar

$$
\text { Düşünce }
$$

\begin{tabular}{|c|c|c|}
\hline İletisim & \multicolumn{2}{|c|}{ Paylaşım } \\
\hline петі̧ा & Ortam içi & Ortam dıșı \\
\hline $\begin{array}{l}\text { - Bilgi paylaşımı çeşitliliği } \\
\text { - Özel iletişim avantajı } \\
\text { - Sesli iletişimin kolaylığı } \\
\text { - Görüşmelerin tekrar } \\
\text { incelenebilmesi }\end{array}$ & $\begin{array}{l}\text { - Fikir alışverişi } \\
\text { - Bilgi paylaşımı } \\
\text { - Toplu sohbetler } \\
\text { - Soruların çekinmeden } \\
\text { yanitlanması }\end{array}$ & $\begin{array}{l}\text { - Üniversitelerin etkileşimi } \\
\text { • Alan uzmanlarından fikir paylaşımı }\end{array}$ \\
\hline \multicolumn{3}{|c|}{ Duygu } \\
\hline Fikir alışverişi & & ffade etme, soruları yanitlama \\
\hline $\begin{array}{l}\text { - Memnun } \\
\text { - Eğlenceli }\end{array}$ & $\bullet$ & \\
\hline
\end{tabular}

Bilgi alışverişi aşamasına göre veriler incelendiğinde, katılımcıların ortamdaki iletişim olanaklarından memnun oldukları, hatta normal bir sınıf ortamına göre daha etkileşimli bir iletişim gerçekleştiğini ifade ettikleri görülmüştür. Bu durumun SL'de bulunan özel yazışma veya özel sesli görüşme özelliklerinden birini kullanan katılımcılar ortamdaki çalışmaları engellemeden kendi aralarında iletişim kurmalarından dolayı meydana geldiği söylenebilir. Elde edilen bulgulara göre katılımcıların büyük bir çoğunluğu ortamdaki iletişim çeşitliliğine bağlı olarak bilgi alışverişinin de çeşitliliği olduğunu ifade ettikleri ve bu durumun ortamdaki çalışmaları daha iyi sonuçlandırdığg görülmüştür. Ortamda gerçekleştirilen 
uygulamalarda ve uygulama başlangıcında/sonunda yapılan fikir alışverişleri, bilgilendirmeler vb. çalışmalardan katılımcıların memnun oldukları, eğlendikleri ve aynı zamanda öğrendikleri bulguları elde edilmiştir. Ortamdaki danışman ya da öğretim üyesi tarafından katılımcılara yöneltilen soruları yanıtlarken çekinen bir katılımcıya rastlanılmamıştır. Aynı şekilde ortaya bir soru sorulduğunda katılımcılardan o soruyu yanıtlamak için istekli olan kişi sayısının da az olmadığı gözlenmiştir. Ayrıca, katılımcılar yanıtlarını verirken ya da bir ifade de bulunurken çekinmeden, rahat bir şekilde kendini ifade ettikleri gözlenmiştir. şunlardır:

Katılımcıların bilgi alışverişi aşaması kapsamındaki ifadelerinden bazıları

-Bir kez diğer ortamlara göre kullanıcı sürekli avatartyla iç içe olduğundan kullanıcı interaktifliği en üst düzeyde. Ses, yazlşma gibi eklentilerde bunu destekliyor zaten... Öğrenciler avatarlarıla etkin bir șekilde katılabiliyor. P9G2

-3 haftalık çalışma hakkında genel düşüncem ortamın etkileşimli bir ortam sunması. Bu ortamla gerçek hayatta tehlikeli ya da imkanları zorlayacak yerlere gitmek uzmanlarla etkileşim sağlamak sanal ortamda olsa bu insanlara bir çevre oluşturmak avantajları arasinda siralanabilir. Dezavantajlarında değinmek gerekirse göz göze iletişim olmadı̆̆ından belki tam bir etkileşim olmayabilir. Second Life ortamında yapacakların sinırlı olması kullanıcılar tarafindan eksik ve sikıcı olarak algilanabilir. P10G3

-Çalışma sırasında arkadaşlarımızla kurduğumuz iletişim konusunda örneğin aklımıza bir soru takıldığında dersin işleyişini bozmamak için arkadaşlarımıza özelden yazıp yardım alabiliriz bu yönden kullanildı̆̆ında bence yararlı oluyor. $\mathrm{P} 10 \mathrm{M}$

-...Tabi hocamızın sanal ortamda konuyla ilgili sormuş olduğu soruyu yanitlamak daha kolay ve zevkli sinıf ortamina göre... Sanal ortamda yapllan ders bana göre daha çok motivasyonu artırıcı özelliği var. Çünkü anında internetten hocamızın yönelttiği soruyla ilgili bilgi edinebilme şansımız oluyor. Ayrıca hocaya sinıf ortamındaki gibi değil de özel görüşme yoluyla sorularımızı yöneltebilme imkânımız var. P12M

-Bölümümde diğer öğretimlerden konuştuğum fakat fazla samimiyetimin bulunmadığı insanlarla ortak önerilerde bulunduk. Tamamen bunu Second Life'in etkili olan faydalarına bağllyorum. Normalde bir insanla reelde bu kadar çok fazla bilgi alışverişinde bulunamaz veya da sohbet edemezdim sanırım. $\mathrm{P} 16 \mathrm{M}$

\section{Bilginin yapılandırılması aşamasına ilişkin bulgular}

Dördüncü aşamaya ilişkin katılımcılardan toplanan üç günlükten elde edilen veriler Tablo 7'de sunulmuştur.

Tablo 7. Bilginin Yapılandırılması Aşamasına İlişkin Temalar

\begin{tabular}{|c|c|c|c|}
\hline \multicolumn{4}{|c|}{ Düșünce } \\
\hline \multicolumn{2}{|c|}{ Grup Çalıșmaları Açısından } & Second Life & Bireysel Çalışmalar Açısından \\
\hline Olumlu & Olumsuz & - Birlikte seyahat etmek & - Bireysel çalış1lırken \\
\hline $\begin{array}{l}\text { - Çok güzel } \\
\text { - Çok verimli } \\
\text { - SL çok } \\
\text { kullanışli } \\
\text { - Etkili karar } \\
\text { - Ürün daha } \\
\text { kaliteli }\end{array}$ & $\begin{array}{l}\text { - İlk toplantı yüz } \\
\text { yüze olmalı }\end{array}$ & $\begin{array}{l}\text { - Bütün katılımcıların fikir } \\
\text { sunması } \\
\text { - Tüm iletişim olanaklarını } \\
\text { kullanarak paylaşımlarda } \\
\text { bulundum } \\
\text { - Seminerler ürün ortaya } \\
\text { koymamızı olumlu etkiledi }\end{array}$ & $\begin{array}{l}\text { paylaşımlarda bulunmak } \\
\text { - Bireysel görevlerde yardımlaşma } \\
\text { - Tasarım sırasında takıldığı } \\
\text { yerlerde arkadaşlarından yardım } \\
\text { almak } \\
\text { - Ders esnasında yardım almak }\end{array}$ \\
\hline \multicolumn{4}{|c|}{ Duygu } \\
\hline \multicolumn{2}{|c|}{ Bireysel ve Grup Çalışmaları } & \multicolumn{2}{|c|}{ Diğer Etkinlikler } \\
\hline \multicolumn{2}{|c|}{$\begin{array}{l}\text { - Gerçek yaşamdakine göre daha güzel } \\
\text { - Heyecanlı } \\
\text { - Çekinmeden bilgi paylaşımı }\end{array}$} & \multicolumn{2}{|c|}{ - Kendini rahatça ifade edebilme } \\
\hline
\end{tabular}

Beş aşamalı modelin dördüncü aşaması olan bilginin yapılandırılması aşamasına yönelik veriler incelendiğinde, katılımcıların tamamının grup çalışması ve bireysel olarak çalışmalar yaptığı gözlenmiştir. Bu çalışmalarla ilgili olarak, grup çalışmalarının gerçek 
yaşamdakine göre daha güzel ve daha verimli geçtiğini belirten katılımcıların çok olmasına rağmen grup çalışmalarının olanak varsa önce yüz yüze yapılmasının daha iyi olacağı yönünde görüş bildiren dört katılımcı bulunmaktadır.

İncelenen verilere göre katılımcıların gerçek yaşamdaki grup çalışmalarında edindikleri tecrübeler ile SL'deki grup çalışmalarında edindikleri tecrübeleri karşılaştırdıkları ve bu doğrultuda SL'deki grup çalışmalarını daha etkili buldukları bulgusuna ulaşılmıştır. Ayrıca katılımcıların büyük bir çoğunluğu, grup çalışması yapılarak alınan kararların daha etkili olduğunu, ortaya koyulan ürünün ise daha kaliteli olduğunu ifade etmişlerdir. Çalışmalar boyunca bütün katılımcıların fikirlerini sundukları, kendilerini rahatça ifade ettikleri bulgularına ulaşılmışıı. Çalışma süresince yapılan gözlemlerde bilginin yapılandırılması aşamasıyla ilgili olarak öne çikan bulgular şu şekildedir:

Katılımcıların tamamı oryantasyon eğitimi sırasında bireysel olarak çalışmıştır. Çalışırken panolarda anlatılan bilgileri inceleme sırasında uygulayarak, pratik yapmış ve sanal karakterlerine o davranışı kazandırmaya çalışmışlardır. Bu çalışmalar sırasında bir yerde takılan ya da sorun yaşayan katılımcıya danışman hemen gerekli yardımı yapmıştır.Güz dönemindeki uygulamalarda katılımcıların çoğunluğunun yaptıkları grup çalışmalarından memnun oldukları ve bahar döneminde öğrendikleri bilgileri bu dönem uygulamaya geçiriyor olmalarından dolayı heyecanlı oldukları ortamdaki sesli ve yazılı iletişimlerde gözlenmiştir.

Ortamda yapılan grup çalışmalarında ve bilgilendirme toplantılarında, katılımcıların fikirlerini, önerilerini çekinmeden paylaştıkları gözlenmiştir. Yanlış ya da hatalı bir bilgi paylaşımı yapıldığında, o kişiye tamamen yapıcı bir şekilde doğru bilgi diğer katılımcılar ya da danışman tarafından verilmiştir. Ortamdaki tasarım çalışmaları sırasında da, katılımcılardan bir işlemin nasıl gerçekleştiğine dair bir soru geldiğinde, o bilgiye sahip olan katılımcılardan biri gerekli açıklamaları ve işlemleri anlatmıştır. Grup çalışmaları halinde yapılan tasarımlarda da hiçbir katılımcı birbirini olumsuz etkilemeden işlemlerini gerçekleştirmiş, ürünlerini ortaya koymaya çalışmışlardır. şunlardır:

Katılımcıların bilginin yapılandırılması aşaması kapsamındaki ifadelerinden bazıları

-SL de en zevk aldığım iş bulding işiydi herkes bir köşede kendi işiyle uğraşıyordu ama aynı zamanda onu nasll yaptın bunu nerden buldun diye iletişimdeydi... Grup çalışması yerine tek tek görev verilip yardımlaşma etkinliği beni daha çok çallşmaya sevk etti. Örneğin bir köprü yaparken bir kişinin fikriyle yapılması ile on kişi arasinda ciddi bir tasarım farkı vardır tabiki on kişinin beğendiği çok daha etkileyici olacaktır bu yüzden ortam bu kadar hoş görünüyordu. $\mathrm{P} 4 \mathrm{M}$

- Building yaparken beceremediğiniz yerleri anında arkadaşlarınızdan yardım alarak düzeltip iyileş̧tirebilirsiniz. Taslak çıkarttıktan sonra da ortak kararlara göre, yapım aşaması başladı. $\mathrm{P} 7 \mathrm{M}$

-Taslak çıkartma sırasında herkes ortamda fikirlerini söyleyerek katkida bulundu. Bu grup çalışmasında gerçekten etkili oldu. Çekinmeden herkes istediği tasarımı dile getirdi. Taslak çıkartma işleminden sonra alanı tasarlarken de deneyerek birçok değişiklik yaptık taslak üzerinde. Herkes bu konuda söz sahibi oldu kim hangi tasarımı isterse anında deneme firsatı bulduk ve oy birliğiyle en çok beğenilen seçildi. $\mathrm{P} 9 \mathrm{M}$

-Bireysel çalı̧̧malarda sorumluluk daha fazla olduğu için zamanında, daha iyi işler ortaya çıkabiliyor. Grupta işini daha az yapan kişiler olabilir. Bu yüzden bireysel çalı̧̧maların grupla desteklenmesi lazım. Yani yine herkes kendinden sorumlu olur, ama işler birleşip daha geniş bir is ortaya koyulabilir. $\mathrm{P} 13 \mathrm{M}$

-...Tasarlayacağımız şeyi düşünürken de taslak çıkartma açısından zamandan tasarruf sağlanmış olunuyor. Reelde çok fazla zaman içerisinde bir taslak çıkarllırken Second Life ortamında bu böyle olmamaktadır. Tasarlanan taslağın içeriğinde yanllş bir bilgi varsa buna engel olunmaktadır. Bir görüş belirtirken de herkesin görüşünü dinlemek açısından Second Life ortamında her grup elemanın ne demek istediği öğreniliyor ya da konuşulanlar kaydedildiği için geri dönüp bakma olanağı sağlanmış oluyor. P16M 


\section{Geliştirme aşamasına iliş̧in bulgular}

Beş aşamalı modelin geliştirme aşamasına yönelik elde edilen verilerin analizinde genel olarak temaların oluşturulması yerine verilerin açıklanarak verilmesinin daha etkili olacağı düşünülmüş ve bu doğrultuda geliştirme aşamasına yönelik bulgular açıklanmıştır.

Elde edilen verilerin analizi sonucunda katılımcıların, çalışmanın sonunda ortaya koyulan sanal çalışma alanında, öğrendikleri ve uyguladıkları tüm bilgileri yansıttıkları bulgusuna ulaşılmıştır. Yani, yapılan ortam tasarımını, edindikleri tecrübeler sonucunda gerçekleştirdiklerini ifade etmişlerdir. Ayrıca katılımcılar sınıf ortamında yaptıkları çalışmalar ile sanal ortamda yaptıkları çalışmaları karşılaştırmış aşağıdaki bulgular ortaya çıkmıştır:

- Katılımcılar, sadece okuyarak işledikleri dersler için sınıfa gitmeyi gereksiz görmüş ve bu derslerin sanal ortamda daha etkili işleneceğini düşünmüşlerdir.

- Sınıf ortamındaki kendi aralarındaki iletişimin çok kısıtlı olduğunu, ortamdaki iletişim olanaklarının çok etkili olduğunu ifade etmişlerdir.

- Sınıf ortamının imkanlarının çok kısıtlı olduğunu, ama sanal ortamın yapılan tasarımlarla bir çok şeye olanak tanıdığını belirtmişlerdir. $\mathrm{Bu}$ yönüyle sanal ortamda yaptıkları çalışmaların daha etkileşimli olduğunu ifade etmişlerdir.

- Sınıf ortamında öğretim üyesinin öğrencileri tamamen yüz yüze görebildiği için öğrencilerle etkileşiminin daha iyi olduğunu, sanal ortamdaki çalışmalarda bu etkileşimin daha az olduğunu ifade etmişlerdir. Ancak, aynı zamanda da sanal ortamda işlenen dersle ilgili olarak öğretim üyesinin sanal ortamda öğretmen-öğrenci etkileşimini sağlamak için güzel yöntemler seçtiğini ifade etmişlerdir.

- Sanal ortamda yapılan çalışmalarda katılımcılar anında internet üzerinden gerekli araştırmaları yapabildiklerini, ancak sınıf ortamında bu durumun pek mümkün olmadığını belirtmişlerdir.

- Sanal ortamın tasarımının sınıf ortamına göre daha iyi olduğunu ve bunun için ortama daha istekli girdiklerini, ortamda hem eğlenip hem de öğrendiklerini ifade etmişlerdir.

- Sanal ortamda öğretmenin ders esnasında ekstradan materyaller ortaya çıkartabileceğini belirten katılımcılar, aynı durumun sınıf ortamında pek mümkün olmadığını ifade etmişlerdir.

Katılımcılar yapılan çalışmanın üç boyutlu sanal ortamda gerçekleşmesi sebebiyle, üç boyutlu tasarım hakkında bilgiler edindiklerini, bu durumun ilgilerini çektiğini ve bu yönde kendilerini daha çok geliştirmek istediklerini belirtmiş; bu sebeplerden dolayı da gerçek yaşantılarında okulda üç boyutlu tasarım (3dmax) dersini seçtiklerini ifade etmişlerdir. Hatta bazı katılımcılar, içlerindeki tasarım yeteneğinin bu çalışma sayesinde ortaya çıktığını ifade etmiştir. Yani çalışma boyunca edindikleri tecrübeler, katılımcıların normal yaşantılarındaki tercihlerini değiştirmelerini sağlamıştır.

Geliştirme aşamasına yönelik katılımcı ifadelerinden bazıları şunlardır:

-Chat ile yazışma, sesli görüşmeler ve özel görüşmeler second life dişındaki uygulamalarda olduğu gibi second life ta da oldukça kullanışlıdır. Ortama bağlanarak aynı anda aynı ortamda yukarıdaki özellikleri uygulayabilmemiz second life'ın en büyük avantajı bence. Internet sayfaları destekliğı ile ortama video resim çekebiliyoruz. P2M

- Yürüme koşma alışılk olduğum durumlardı oyunlardan ama uçmayı ilk defa denedim ve hem uzun mesafeyi kısa zamanda almayı hem de eğlenceli geldi bana. Bu dönem 3 dmax derste gelince üzerine iyice ilgim arttı ve aslinda seçmeli olan 3 dmax dersine beni itende second life deneyimim oldu... P4M

-Ortama ilk girdiğimde çok yabancllık çekmedim daha önce oynadı̆̆ım online oyunlardan böyle bir ortama aşinaydım. Ama tabi ki bu bir oyun değildi ve oyun bilim kurgu eseriydi fakat SL gerçek hayata benzer koşullarla oluşturulmuş bir ortamdı o yüzden benim ilgimi çekmeyi başardl. SL de ders işlemek derse karşı tutumumu daha olumlu hale getirdi. P5M

-Second Lifetaki tüm deneyimlerim (ürün), uygulamanın her aşamasındaki edindiğiniz tecrübelerin toplamıdır. Kesinlikle her çalışma bize bir şeyler öğretti. P6M

-Oryantasyon da ögrrendiklerimin hepsi çok yararl oldular ve tabi sl ilk girdiğimde kendi yaşadı̆̆ım deneyimlerde olmak üzere hepsini uygulamanın gerekli yerlerinde kullandım. İşletim 
sistemleri dersinde paylaşılan bilgiler, slaytlar, videolar da uygulamalar da yardımcı oldu ortamda ki becerilerimize. P7M

-Second life 'a ilk girdiğimizde karşımıza çılkan ortam bizleri motive etti. Oryantasyon alanlarında kazandığımız bilgileri anında uygulayarak öğrenme imkanı bulduk. İşletim sistemleri dersi, Texas State Üniversitesi'nin sanal kampüsüne yaptığımı gezi ve oradaki hocaların bizlere yaptı̆̆ sunumlar ve bu sunumlardaki bilgi ve belge paylaşımı çalışmalarımızı olumlu yönde etkiledi. Haftalık toplantılarımı ve ders işlediğimiz alanını tasarım aşamalarımızda öğrendiğimiz bilgilerin tümünü uyguladık ve sonunda işlediğimiz derste bunun meyvesini yemiş olduk. P9M

-...Önceden tasarım konusunda yaptığımız çalı̧̧malardan yararlandık. Ayrıca ben tasarım yaparken bu dönem gördügü̈m 3dsmax dersi de bana kolayllk sağladl. Ama bir şeyler tasarlayabilip ortaya bir ürün koyabildik. P10M

-İstediğiniz ürünü rahatllkla oluşturabiliyorsunuz ve gerekli yerlerde kullanımın ayarlayabiliyorsunuz. Ürününüzü siz tasarlyyorsunuz ve istediğiniz tasarımı yapmakta özgürsünüz. Sanırım tasarımcı ruhumu kontrol etmede gayet başarllı oldu. Ayrıca istediğiniz ve bağlantıya geçebileceğiniz başka bir ortamla eşzamanlı olarak birlikte çallşabilir ve ürün oluşturabilirsiniz. P11M

-...Oryantasyon yapıldı̆̆ında second life ortaminin değişik yönlerini görmeye başladım sadece ben değil eminim diğer arkadaşlarımda aynı şekilde düşünmüsslerdir. Konuşmalar ve yapılan yazışmalar herkesin aynı ortamda belirlenen saat doğrultusunda bulunması aynı sinı ortamın yansıtması açsından insan kendini bir an sinfftaymış gibi hissediyor. Özellikle de bu son xxx hocamızla işlediğimiz işletim sistemleri dersimizde ben açıkçası sinıftaki ortamdan farklı bir ortam görmedim. P12M

-Ortam tasartmı ve building sayesinde hem kendi görsel hafizamızın geliştiğini düşünüyorum. Ortaya konulan ürün gerçekten bütün second life ortamındaki arkadaşlarımızın başarısıdır diye düşünüyorum.. çünkü herkes bir işin ucundan tuttu bu gerçekten bir ekip çallşmasinin başarllı bir sonucudur. P15M

\section{Sonuç ve Tartışma}

Araştırmanın amacı; üç boyutlu sanal ortamlardan biri olan Second Life ortamında beş aşamalı model temel alınarak katılımcılara Second Life'ın kullanımına yönelik oryantasyon eğitimi verilmesi, eğitsel amaçlı bir çalışma ortamı hazırlanmasının sağlanması, hazırlanan ortamda eğitim-öğretim aktiviteleri yapılarak katılımcıların ortamdaki deneyimleri hakkında görüşlerinin alınması ve uygulanan beş aşamalı modelin etkililiğinin belirlenmesidir. Bu amaçla BÖTE Bölümü öğrencilerinden gönüllü olarak çalışmaya katılan 19 öğrenci ile SL ortamında beş aşamalı model temel alınarak bir oryantasyon eğitimi verilmiş ve ardından bir ortam tasarımı yapılıp, o ortamda bir uzaktan eğitim uygulaması yapılmıştır. Bu süreçte de ortamda çeşitli seminerler verilmiş, farklı çalışmalar da yapılmıştır. Çalışmalar süresince çeşitli veri toplama araçları ile veriler toplanmış, analiz edilmiş ve bulgular oluşturulmuştur.

Katılımcılar tarafından yapılan ortam tasarımlarından dolayı katılımcıların eğlendikleri ve ortamda çalışma yapmaya yönelik motivasyonlarının arttı̆̆ı, elde edilen bulgular arasındadır. Salmon ve diğerlerinin (2010) yapmış olduğu araştırmada da benzer sonuçlar elde edilmiştir. Ayrıca, araştırmacı tarafından yapılan SL'yi tanıtmaya ve temel becerileri kazanmaya yönelik anlatımlar sayesinde de katılımcıların hem gerekli bilgileri edindiği hem de motivasyonlarının arttığı söylenebilir. Katılımcıların öğrendikleri temel bilgiler 1şığında gerekli işlemleri gerçekleştirip SL'ye başarılı bir şekilde bağlanmış ve çalışma ortamında toplanmışlardır. Esgin, Pamukçu, Ergül ve Ansay'ın (2011) ve Dinçer'in (2008) yaptıkları araştırmanın sonuçlarına göre, gerekli işlemlerin gerçekleştirilmesi ve SL'e bağlanılması, danışmanlık odasına erişim gibi işlemlerde öğrenciler bazı sıkıntılar yaşamışlardır. Bu bağlamda, beş aşamalı modelin birinci aşaması ile gerçekleştirilen eğitimle öğrencilerin diğer çalışmalara göre daha başarılı oldukları, dolayısıyla katılımcıların beş aşamalı modelin ilk aşamasını gerçekleştirdikleri sonucuna ulaşılabilir. Ayrıca yapılan çalışmalarla katılımcıların motivasyonları daha da arttığı elde edilen bulgular arasındadır ve bu sonucu desteklemektedir.

Elde edilen bulgulara göre, katılımcıların ortamda kendilerini rahatça ifade ettikleri ve soruları çekinmeden yanıtladıkları görülmüştür. Bu sonuca ulaşılmasında yapılan ortam 
tasarımlarının iyi olmasının, araștırmacının ortamdaki rolünü iyi yapmasının ve katılımcıların tamamen gönüllü olarak katılmalarının etkili olduğu söylenebilir. Benzer şekilde, Bezir, Çukurbaşı ve Baran'ın (2011c) yapmış oldukları çalışmada da ortam tasarımının iyi olmasından dolayı sınıf ortamına kıyasla kendilerini daha rahat hissettiklerini ve motivasyonlarının yüksek olduğu bulgularına ulaşılmıştır.

SL'nin birçok olanakları olmasına rağmen, zaman zaman meydana gelen teknik sıkıntılar sebebiyle, ortamdaki etkileşim ne kadar yüksek olursa olsun, sorunlar ortaya çıkmaktadır. Bu sorunlardan biri internet hızındaki düşmeden dolayı meydana gelen sesli iletişimin kopmasıdır. Hatta bazı zamanlarda SL ile bağlantı tamamen kopmaktadır. Bunun dışında sadece Türkçe bilen kullanıcılar için Türkçe dil seçeneği olmayan ya da test aşamasında Türkçe seçeneği olan SL'nin kullanımı bazen zorlaşmaktadır. Bu tarz sıkıntıların, katılımcıların motivasyonunu olumsuz yönde etkileyebileceği söylenebilir. Alan yazında yer alan araştırmalarda da benzer sonuçların ortaya çıktığı görülmektedir (Çukurbaşı vd., 2011; Esgin vd., 2011; Çoban ve Göktaş, 2013).

Ortamdaki iletişim olanaklarının yapılan tüm etkinliklerde öğrenciler açısından faydalı olduğu görülmüştür. Gerek eğitim ve seminerlerde gerekse ortamda yapılan çalışmalarda katılımcılar özel iletişim seçeneklerinden istediklerini kullanarak rahatça birbirleriyle, danışmanla ya da ortamdaki diğer kişilerle iletişime geçebilmiş ve başkalarını rahatsız etmeden rahatça iletişim kurmuştur. Ayrıca genel iletişim seçenekleri ile de aynı anda ortamda bulunan diğer kişilerle iletişimlerini sağlamışlardır. Bezir ve diğerlerinin (2011b) yaptıkları araştırmada da iletişim olanaklarının faydalı olduğu görülmüştür.

Katılımcılar sanal ortamda yaptıkları işlemlerde ve öğrenme aktivitelerinde, sosyal etkinliklerde sanki gerçek yaşamda hareket ediyorlarmış gibi düşünmüş ve normal yaşantılarında gösterecekleri tepkileri/hareketleri ortamda göstermeye çalışmışlardır. Chen (2016) çalışmasında öğrenenlerin teknoloji odaklı, çoklu görevleri içeren ve yaratıcı öğrenme stillerini barındıran SL ortamının öğrenenlerin sanal ortam içerisinde gerçek yaşam deneyimlerine sahip olmasını sağladığını belirtmiştir. Bununla birlikte Şahin (2016) çalışmasında SL ortamının tasarım olanakları ile eğitime farklı bir boyut kazandırdığı; görsel açıdançalışılan konunun içerisindeymiş hissini meydana getirdiği, konunun anlaşılmasını kolaylaştırdığı, özgün, öğrenmeye ve bilgiyi pekiştirmeye yardımcı olduğu belirtilmiş ve farklı öğrenme stiline sahip öğrencilerin öğrenmelerine katkı sağlayacağ ifade edilmiştir. Dolayısıyla bu durum, araştırmada katılımcıların ortamdaki faaliyetleri içselleştirdiğini yani, gerçek yaşamla ilişkilendirdiğini ve öğrenmelerini gerçekleştirdiklerini göstermektedir. Ayrıca katılımcıların sanal karakterlerini kendilerine benzeyecek ya da hayal ettikleri bir karaktere benzeyecek şekilde biçimlendirmeleri, gerçek yaşamla ilişkilendirmelerini destekleyici başka bir sonuç olmaktadır. Gerek iletişim olanakları ile gerekse ortamdaki sosyal faaliyetler ve ortamı benimsemeleri ile katılımcıların çevrimiçi sosyalleşme aşamasını gerçekleştirdikleri sonucuna ulaşılabilir. Salmon ve diğerlerinin (2010) yaptıkları çalışmada da benzer sonuçlara ulaşılmıştır.

Katılımcılar yapılan çalışmalar boyunca birbirleriyle, danışmanla ya da ortamdaki diğer sanal karakterlerle bilgi alışverişlerinde bulunmuş, yapılan çalışmalarda da önerilerde bulunmuş ve beyin fırtınası ile iyi sonuçlar alınmasında katkılar sağlamışlardır. Diğer katılımcılara yardımcı oldukları ve ortak bir işlemi gerçekleştirmek için bilgi paylaşımlarını çekinmeden yaptıkları gözlenmiştir. Bu bağlamda katılımcıların bilgi alışverişi aşamasını gerçekleştirdiği söylenebilir. Ayrıca, danışmanın tüm uygulama boyunca yaptığı danışmanlık ve katılımcıların birbirleriyle bilgi paylaşmalarına yönelik rehberlikle katılımcıların birbirleriyle etkili bir bilgi paylaşımı yapmalarını sağlamıştır. Böylece üçüncü aşamanın katılımcılar tarafindan gerçekleştirilmesinde danışmanın etkili olduğu söylenebilir. Salmon ve diğerlerinin (2010) yaptıkları çalışmada da üçüncü aşamanın gerçekleşmesinde danışman etkin rol üstlenmiştir. Ayrıca, Çukurbaşı ve diğerlerinin (2011) yapmış olduğu araştırmada yapılacak çalışmalarda ortamda bir danışmanın olması önerilmektedir. Yapılan oryantasyon eğitimi süresince bilgiler katılımcılara küçük parçalar halinde ve aşama aşama verilmiştir. $\mathrm{Bu}$ yönüyle de verilen oryantasyon eğitiminin katılımcıların üçüncü basamağı gerçekleştirmelerinde etkili olduğu söylenebilir. 
Ortamda yapılan çalışmaların bir bölümü grup çalışmaları halinde bir bölümü de bireysel çalışmalar halinde gerçekleştirilmiştir. Bu bağlamda katılımcılar yaptıkları grup çalışmalarında işbirliği içinde çalışmış ve ortamda güzel tasarımlar yapılmasında etkili olmuşlardır. Ayrıca, gerek bireysel olsun gerekse grup çalışması olsun, katılımcıların birbirleriyle yaptıkları paylaşımlarla yapılan çalışmayı daha güzel bir hale getirdikleri söylenebilir. Katılımcıların bilgi paylaşımları yaparak, ortamda ders işleyerek ve diğer eğitsel aktivitelere katılarak öğrendikleri bilgileri yapılandırdığı dolayısıyla beş aşamalı modelin dördüncü aşamasını gerçekleştirdiği söylenebilir.

Beşinci aşama olan geliştirme aşamasında, katılımcıların uygulama süreci sonundaki SL'de yansıttıkları tecrübelerine odaklanılmıştır (Salmon vd., 2010). Geliştirme basamağında katılımcıların, beş aşamalı model ile bireysel amaçlara ulaşmaları ve diğer öğrenme biçimleriyle çevrimiçi ortamdaki öğrenme deneyimlerini entegre etmeleri incelenmiş ve bu bağlamda katılımcılar, üç boyutlu dünyada kendi üstbilişsel öğrenme becerilerini geliştirmişlerdir (Salmon vd., 2010). Elde edilen veriler geliştirme aşamasına göre incelendiğinde katılımcıların, uygulama sürecinin sonunda ortaya koyulan çalışma ortamıyla ve gerçek yaşamdaki tercihleriyle beş aşamalı modelin geliştirme aşamasını gerçekleştirdikleri söylenebilir.

Araştırma neticesinde beş aşamalı model temel alınarak gerçekleştirilen SL'in kullanımına yönelik oryantasyon eğitimi, eğitimi alan katılımcılarla ortam tasarımı yapılması ve bu alanda aynı katılımcıların öğrenci olarak katıldıkları bir ders işlenmiştir. Bu bağlamda beş aşamalı model temel alınarak yapılan çalışmalar sonucunda, katılımcıların SL'yi etkili kullanmayı ögrendikleri, birlikte güzel bir çalışma ortamı tasarladıkları ve bu ortamda başarılı bir şekilde ders işledikleri; öğrenmelerini gerçekleştirdikleri görülmüştür. $\mathrm{Bu}$ araştırma kapsamında elde edilen sonuçların Karaman ve Orhan Özen (2016) tarafından yapılan araştırma sonuçları ile benzerlik gösterdiği görülmüştür. Ayrıca, sanal ortamdaki tecrübelerini gerçek yaşamla ilişkilendirdikleri ve bu ilişkilendirmenin olumlu yönde olduğu sonuçlarına ulaşılmıştır. SL ortamı ile gerçekleştirilen öğrenme öğretme faaliyetlerinin, gerçek yaşamda gerçekleştirilen faaliyetlerle büyük ölçüde birbirine yakın sayılabilecek öğrenme çıtılarına ve öğrenci memnuniyetine sahip olduğu görülmüsstür (Vrellis, Avouris ve Mikropuulos, 2016).

Beş aşamalı model gereği ortamda bir danışman bulunmuştur. Danışmanın ortamda aktif olarak bulunmasının öğrencilerin öğrenmelerine olumlu yönde katkı sağladığı, yaptıkları çalışmalarda danışman gerektiğinde destek vereceği için daha rahat oldukları ve bu doğrultuda da güzel ürünler ortaya koydukları görülmüştür. Ayrıca danışmanın varlığı ve yapmış oldukları rehberlik sayesinde, katılımcıların beş aşamalı modelin gerçekleştirmelerinde etkili olduğu sonucuna ulaşılabilir.

Ortamda yapılan derslerde öğretim elemanının istediği zaman istediği bir materyali hemen kullanabilecek olması ya da o anda yeni materyaller edinebilmesi ve katılımcıların internet aracılığıyla istedikleri bilgiye hızlı bir şekilde ulaşabilmelerinin ortamda işlenecek derslerin daha da verimli hale getirdiği sonucuna ulaşılabilir. Ayrıca, ortamdaki yazılı iletişim verilerinin saklanması özelliği ile geriye dönük yazışmalar tekrar tekrar incelenebilmektedir. $\mathrm{Bu}$ durumda katılımcı yazılı olarak aktarılan bilgilere tekrar tekrar bakabilmektedir. Sinıf ortamında bu durum mümkün olmayacaktır. Bunun dışında ortamda bulunan derse yönelik eğitsel materyallere katılımcının sınıf ortamının aksine istediği zaman istediği yerden ulaşabilmesinin öğrenilen bilgilerin tekrarının sağlanmasında etkili olacağı söylenebilir. Sonuç olarak, ortamda işlenen dersin beş aşamalı modelin tüm basamaklarının gerçekleştirilmesinde etkili olmasıyla birlikte, özellikle üçüncü, dördüncü ve beşinci basamakların gerçekleştirilmesinde daha çok etkili olduğu söylenebilir.

Elde edilen bulgular ışığında ortaya çıkarılan sonuçlar değerlendirilerek yapılacak olan benzer çalışmalar için aşağıdaki öneriler yapılmıştır.

- Farklı alanlarda eğitim alan katılımcılarla çalışılması ve alanlara göre katılımcıların eğilimleri incelenebilir. 
- Ortamda yapılacak dersler tek bir uygulama yerine, zamanlaması daha iyi planlanıp bir haftalık uygulamalar halinde olabilir. $\mathrm{Bu}$ durumda ortamda verilen eğitimin etkililiği daha iyi incelenebilir.

- Belirlenecek örneklem daha geniş tutulabilir ve bu örneklemin düzenli olarak katılımı sağlanabildiği takdirde daha derinlemesine veriler elde edilebilir.

- Uluslararası seminer verildiği sırada ortamdaki katılımcı sayısı yüksek olduğunda (50 civarı) SL'de hata meydana gelmekte ve o anda üzerinde bulunulan alanda problemler yaşanmıştır. $\mathrm{Bu}$ yüzden yapılacak çalışmaların sağlıklı yürütülmesi için katılımcı sayısına dikkat edilmesi önerilmektedir.

\section{Katkısı Olanlar}

Bu çalışma "Üç Boyutlu Sanal Ortamlarda Beş Aşamalı Modelin Uygulanması” başlıklı yüksek lisans tezinden üretilmiştir.

\section{Kaynaklar}

Arslan, B. (2007). Web 2.0 teknikleri ve uygulamaları. XII. Türkiye'de Internet Konferansi. Ankara.

Ata, F. (2011). Üniversite öğrencilerinin web 2.0 teknolojilerini kullanım durumlart ile bilgi okuryazarlı̆̆ öz-yeterlik algıları arasındaki ilişskinin incelenmesi. Yayımlanmamış yüksek lisans tezi, Dokuz Eylül Üniversitesi, Eğitim Bilimleri Enstitüsü.

Bezir, Ç., Çukurbaşı, B. ve Baran, B. (2011a). Second life ortamında rol oynama tekniği ile yabanc1 dil etkinlikleri tasarım süreci ve uygulanmasi. 5th International Computer \& Instructional Technologies Symposium. 22-24 Eylül 2011, Frrat Üniversitesi, Elazığ.

Bezir, Ç., Çukurbaşı, B., \& Baran, B. (2011b). Student teacher and context interaction in second life foreign language education classroom: some implications for practices. Association For Educational Communications And Technology Symposium. 8-12 Kasım 2011, Jacksonville, Florida.

Bezir, Ç., Çukurbaşı, B., \& Baran, B. (2011c). Second life yabancı dil öğretim ortamında altı şapkalı düşünme tekniğinin uygulanması. 11th International Educational Technology Conferance. 25-27 May1s 2011, İstanbul.

Bulu, T.S. ve İşler, V. (2011). Second Life ODTÜ Kampüsü. Akademik Bilişim 2011. 2-4 Şubat 2011, İnönü Üniversitesi, Malatya.

Burgess, M. L., Slate, J.R., Rojas-LeBouef, A., \& LaPrairie, K. (2010). Teaching and learning in second life: using the community on inquiry (CoI) model to support online instruction with graduate students in instructional technology. Internet and Higher Education, 13, 84-88.

Chen, J.C. (2016). EFL learners' strategy use during task-based interaction in Second Life. Australasian Journal of Educational Technology, 32(3), 1-17.

Comscore. (2012). 23 Mart 2012 tarihinde Comscore.com: http://www.comscore.com/Press_Events/Press_Releases/2011/11/comScore_Releases_ Overview_of_European_Internet_Usage_in_September_2011 adresinden alındi.

Crocker, R. (2011). Creating and analyzing data in qualitative research. Qualitative Research In Education: Eğitimde Nitel Araştırmalar Semineri. 21-22 Mart 2012, İzmir.

Çekinmez, Ö. (2009). Web 2.0 teknolojileri ve açık kaynak kodlu ögretim yönetim kullanılarak uzaktan eğitim sistemi uygulaması. Yayımlanmamış yüksek lisans tezi, Sakarya Üniversitesi, Fen Bilimleri Enstitüsü.

Çoban, M. ve Göktaş, Y. (2013). Üç boyutlu sanal dünyalarda öğretim materyalleri geliştiren tasarımcıların karşılaştıkları sorunlar. Mersin Universitesi Eğitim Fakültesi Dergisi, 9(2), 275-287.

Çukurbaşı, B., Baran, B., Çolak, C., \& Doğusoy, B. (2010). Second life users' views about second life use in education: A case of Turkey. Association For Educational Communications And Technology Symposium. 26-30 Ekim 2010, Anaheim, California. 
Çukurbaşı, B., Bezir, Ç. ve Karamete, A. (2011). Üç boyutlu sanal ortamlarda oryantasyon. 5th International Computer \& Instructional Technologies Symposium. 22-24 Eylül 2011, Firat Üniversitesi, Elazığ.

Dinçer, G.D. (2008). Sanal dünyaların uzaktan eğitim danışmanlık hizmetlerinde kullanımı: Second Life örneği. Yayımlanmamış yüksek lisans tezi, Anadolu Üniversitesi, Sosyal Bilimler Enstitüsü.

Durusoy, O. (2011). Öğretmen yetiştirmede web 2.0 ve dijital video teknolojilerinin kullanılarak ögretmenlik öz-yeterliğinin geliştirilmesi. Yayımlanmamış yüksek lisans tezi, Balıkesir Üniversitesi, Fen Bilimleri Enstitüsü.

Esgin, E., Pamukçu, B.S., Ergül, P. ve Ansay, S. (2011). 3-boyutlu çevrimiçi sosyal ortamların eğitimde kullanılmasının öğrenci başarısı ve motivasyonuna etkisi: Secondlife uygulamas1. 5th International Computer \& Instructional Technologies Symposium. 2224 Eylül 2011, Firat Üniversitesi, Elazı ğ.

Fisher, A. (2010). Learning in virtual worlds. Centre for Integrative Learning, s. 46-58.

Horzum, M.B. (2010). Öğretmenlerin web 2.0 araçlarından haberdarlığı, kullanım sıklıkları ve amaçlarının çeşitli değişkenler açısından incelenmesi. Uluslararası İnsan Bilimleri Dergisi, 7,1.

Internet World Stats. (2015). Internet Usage in the European Union. 25 Nisan 2016 tarihinde Internet Usage in the European Union adresinden alınd.

Karaman, M.K., \& Orhan Özen, S. (2016). A survey of students' experiences on collaborative virtual learning activitiesbased on five-stage model. Educational Technology \& Society, 19(3), 247-259.

Keskin, Y. (2011). DKAB bölümleri öğrencilerinin bilgisayar ve internet kullanma durumları ve yeterlikleri. Ondokuz Mayls Üniversitesi İlahiyat Fakültesi Dergis,. 30, 211-233.

Kuzu, E. B. (2014). Bilişsim teknolojileri ögretmen adayları arasında çevrimiçi sosyal ağların ögretim amaçlı kullanımı.Yayınlanmamış doktora tezi, Anadolu Üniversitesi, Eğitim Bilimleri Enstitüsü.

Lowe, C. (2009). Graduate student perceptions of learning in a virtual world. 25th Annual Conference on Distance Teaching \& Learaning. Wisconsin Technic University, ABD.

Muirhead, B. (2002). E-tivities: The key to active online learning. Educational Technology \& Society, 5(4), 179-181.

Nottingham's Web Campus in Second Life. (2009). The Hub Learning and Teaching at Nottingham, 29-30.

Petrakou, A. (2010). Interacting through avatars: virtual worlds as a context for online education. Computers \& Education. 54(4). 1020-1027.

Rymaszewski, M., Au, W. J., Wallace, M., Winters, C., Ondrejka, C., \& Batstone-Cunningham, B. (2007). Second Life the official guide. New Jersey: Wiley Publishing.

Salmon, G. (2000). E-moderating: The key to teaching and learning online. Londra: RoutledgeFalmer.

Salmon, G. (2004a). All things in moderation. 17 May1s 2012 tarihinde All Things In Moderation Ltd: http://www.atimod.com/e-moderating/fivestepflash.htm adresinden alindi.

Salmon, G. (2004b). All things in moderation. 17 May1s 2012 tarihinde All Things In Moderation Ltd: http://www.atimod.com/e-tivities/5stage.shtml adresinden alındı.

Salmon, G., Nie, M., \& Edirisingha, P. (2010). Developing a five-stage model of learning in Second Life. Educational Research, (52), 169-182.

Second Life Grid Survey. (2016). Second life grid survey - Region database. 25 Nisan 2016 tarihinde http://gridsurvey.com/adresinden alınd.

Second Life Grid Survey Region Database. (2012). 25 Haziran 2012 tarihinde Second Life Grid Survey: www.gridsurvey.com adresinden alınd.

Şahin, G. (2016). Second Life oyununun sosyal bilgiler ögrretiminde deneyimsel öğrenmeye yönelik bir model olarak kullanılması. Yayımlanmamış yüksek lisans tezi, Muğla Sitkı Koçman Üniversitesi, Eğitim Bilimleri Enstitüsü. 
Şahin, Y.L. (2013). Teknolpedagojik eğitimde web 2.0 araçları. Kabakçı Yurdakul, I. içinde, Teknopedagojik eğitime dayalı ögretim teknolojileri ve materyal tasarımı. s. 163-192. Anı Yayınc1lık, Ankara.

Texas State University - San Marcos. (2008). 6 Nisan 2012 tarihinde Virtual Field School Project: http://elcerritoproject.blogspot.com/ adresinden alındı.

Tokel, S. ve Cevizci Karataş, E. (2014). Three-Dimensional virtual worlds: Research trends and future directions. Mersin Üniversitesi Eğitim Fakültesi Dergisi, 10(1), 1-12.

Türkiye İstatistik Kurumu. (2011). Hanehalkı bilişsim teknolojileri kullanım araştırması, 2015. 15 Şubat 2016 tarihinde http://www.tuik.gov.tr/PreHaberBultenleri.do?id=18660 adresinden alınd.

Türkiye İstatistik Kurumu. (2015). Hanehalkı bilişsim teknolojileri kullanım araştırması, 2011. 25 Nisan 2012 tarihinde http://www.tuik.gov.tr/PreHaberBultenleri.do?id=8572 adresinden alındi.

Türkiye İstatistik Kurumu. (2016). Hanehalkı bilişsim teknolojileri kullanım araştırması, 2011. $29 \quad$ Eylül $2016 \quad$ tarihinde http://www.tuik.gov.tr/PreIstatistikTablo.do?istab_id=45adresinden alındı.

Vasileiou, V.N. \& Paraskeva, F. (2010). Teaching role-playing instruction in Second Life: An exploratory study. Journal of Information, Information Technology, and Organizations. $5(1), 25-50$.

Vrellis, I., Avouris, N., \& Mikropoulos, T.A. (2016). Learning outcome, presence and satisfaction from a science activity in Second Life. Australasian Journal of Educational Technology, 32(1).59-77.

Walker, V.L. (2009). 3D virtual learning in counselor education: Using Second Life in counselor skill development. Journal of Vitual Worlds Research, 2(1), 1-14.

Yıldırım, A. ve Şimşek, H. (2008). Sosyal bilimlerde nitel araştırma yöntemleri. Ankara: Seçkin Yayıncilik.

Yükseltürk, E. ve Top, E. (2013). Web 2.0 teknolojilerinin öğretmen eğitiminde kullanımı. Çağıltay, K. ve Göktaş, Y. içinde, Öğretim teknolojilerinin temelleri: Teoriler, araştırmalar, eğilimler (s. 665-680). Ankara: Pegem Akademi.

\section{Extended Abstract}

\section{Introduction}

Second Life (SL) is a flexible and strong online environment ensuring educators and students to meet any place in the world and meet and interact in a 3-dimensional setting (Nottingham's Web Campus in Second Life, 2009). Owing to this characteristic, SL environment is also used as a distance learning setting since it consists of an opportunity to develop both synchronous applications where learning-teaching activities are conducted simultaneously and asynchronous applications where they are conducted in different times. One or more teaching methods, technique and learning approach are used in education-teaching activities that are conducted in SL generally (Burgess et al., 2010). In addition to the methods and techniques used during education-teaching activities, there are application development models in place as well. Five Stage Model (FSM) is one of these application development models. Differing from other virtual environments, SL is three dimensional social application software and the users can do whatever they dream and want in the environment. Salmon and others (2010) applied FSM in SL setting in their study and organized the steps of this model to be suitable to SL. Therefore, in the present research, it was aimed that orientation education was given to the participants directed to SL usage based on FSM in SL setting which is one of multi user virtual environments (MUVE), and education-teaching activities were conducted in the prepared environment and opinions of the participants about their experiences in the environment were received, and the efficacy of the applied FSM was determined. 


\section{Method}

Case study, one of qualitative research methods, was used in the research. Criterion sampling, one of purposeful sampling methods, was used to determine the study group. 19 sophomore students enrolled in a formal education and evening education at Balikesir University Faculty of Necatibey Education Computer and Instructional Technologies Educational Department and fulfilling the determined criterion and participating in the study absolutely voluntarily made up the study group.

The part of the research in 2010-2011 spring semester lasted six weeks, and the part in 2011-2012 fall semester lasted five weeks. Orientation training was given directed to the usage of SL based on FSM in the spring semester; and in the fall semester, a study environment was designed in SL in company with the participants. The study was completed by teaching a lesson with distant learning in the designed virtual environment. In addition to the informing presentation conducted with the students for sampling selection, the study was conducted in the laboratory setting face-to-face with the students only during the first two weeks in the research process, and all other applications were carried out over SL. The researcher and participants connected to SL from their locations and conducted the studies. An internet site was prepared by the researcher and the students were ensured to become members in the system in order to inform the participants during the research process, to ensure communication out of the application times and to collect data from distance.

Data were collected in the research via daily, semi-constructed interview and observation. Content analysis was made to analyze the collected data. In this context, the data collected by interviews and diaries were scrutinized in detail and coded; and the relationship between these codes was examined, the themes were revealed and the relationships between the themes were explained. The data obtained as a result of the analysis were supported by the observation results and more meaningful results were revealed.

\section{Results and Discussion}

The acquired data proved that the participants had fun due to the environment designs made by the participants and their motivation for studying in the environment improved. Furthermore, it can be stated that the participants both obtained the necessary information and their motivation improved owing to the explanations of the researcher on introduction of SL and gaining basic skills. In the light of the basic information that the participants learned, they carried out the required procedures and connected to SL successfully and gathered in the study environment. In this context, it can be deduced that the students were more successful according to the other studies by the education given in the first stage of this FSM, and thus the participants accomplished the first stage of FSM.

Based on the acquired findings, the participants expressed themselves comfortably in the environment and answered the questions without hesitation. It can be stated that good environmental designs and the researcher conducting his role in the environment and the participants being absolutely volunteers were effective on reaching this result. Despite many opportunities of SL, problems arise due to occasional technical troubles no matter how great is interaction in the environment. One of these problems is the disconnection of voice communications occurring due to drop in internet speed. In addition, SL usage with no Turkish language selection and with Turkish selection in the test stage can make the usage difficult sometimes for users who know only Turkish. Such problems affect motivation of the participants negatively.

It was concluded that the communication opportunities in the environment were beneficial for the students in all activities. The participants thought that they were like acting in real life in the procedures they carried out in the virtual environment and they attempted to show the reactions/behavior that they would display in their normal life. This situation showed that the participants internalized their activities in the environment, that is to say they related them with real life. It can be deduced that the participants accomplished online socializing by both 
communication opportunities and social activities in the environment and by adopting the environment.

The participants exchanged information with each other, the advisor or other virtual characters in the environment during the study and made suggestions in the studies and contributed to receiving good results by brainstorming. It was observed that they assisted other participants and exchanged information freely to carry out a common procedure. In this context, the participants accomplished the information exchange stage.

A part of the studies was carried out in the environment as a group study, and a part was carried out as individual studies. The participants exchanged information, learned lessons in the environment and constructed the knowledge that they learned by participating in other educational activities, thus they accomplished the fourth stage of FSM.

The participants reaching their individual objects by FSM and integrating their learning experiences in the online environment by other learning forms in the development step was scrutinized and in this context, the participants developed their own metacognitive learning skills in the three-dimensional world (Salmon and others, 2010). Considering the obtained data according to the development stage, accomplishment of the development stage of FSM with the study environment by the participants was revealed at the end of the application process and by their preferences in real life.

As a result of the research, orientation education directed to SL use was carried out based on FSM, a class was taught on environment design by the participants who received the education and with the participation of the same participants as students in this field. In this context, as a result of the studies based on FSM, it was deduced that the participants learned how to use SL effectively, designed a pleasant study environment together and learned lessons successfully in this environment; hence they related their experiences in the virtual environment with real life and this relating was positive. 